\title{
Synthesis of Porous Octahedral ZnO/CuO Composites from Zn/Cu-Based MOF-199 and Their Applications in Visible-Light-Driven Photocatalytic Degradation of Dyes
}

\author{
Tran Thanh Minh, ${ }^{1}$ Nguyen Thi Thanh Tu, ${ }^{2}$ Tran Thi Van Thi, ${ }^{1}$ Le Thi Hoa, ${ }^{1}$ \\ Hoang Thai Long, ${ }^{1}$ Nguyen Hai Phong, ${ }^{1}$ Thong Le Minh Pham, ${ }^{3}$ and Dinh Quang Khieu ${ }^{1}{ }^{1}$ \\ ${ }^{1}$ University of Sciences, Hue University, 530000, Vietnam \\ ${ }^{2}$ Institute for Environmental Science, Nguyen Tat Thanh University, 700000, Vietnam \\ ${ }^{3}$ Institute of Research and Development, Duy Tan University, 550000, Vietnam \\ Correspondence should be addressed to Dinh Quang Khieu; dqkhieu@hueuni.edu.vn
}

Received 22 June 2019; Revised 4 September 2019; Accepted 16 September 2019; Published 14 October 2019

Academic Editor: Sesha Srinivasan

Copyright (c) 2019 Tran Thanh Minh et al. This is an open access article distributed under the Creative Commons Attribution License, which permits unrestricted use, distribution, and reproduction in any medium, provided the original work is properly cited.

\begin{abstract}
In the present paper, a porous octahedral $(\mathrm{ZnO} / \mathrm{CuO})$ composite is synthesized from zinc/copper-based metal-organic framework-199, and its applications in visible-light-driven photocatalytic degradation of dyes are demonstrated. The precursors of Zn-BTC, Cu-BTC, and Zn/Cu-BTC (BTC: benzene-1,3,5-tricarboxylate) were synthesized using a microwave-assisted method. Benzene-1,3,5-tricarboxylate acts as a sacrificial template and was removed from the precursors via thermal decomposition to form $\mathrm{CuO}, \mathrm{ZnO}$, and $\mathrm{ZnO} / \mathrm{CuO}$. $\mathrm{ZnO} / \mathrm{CuO}$ with a large specific surface area of $32.5 \mathrm{~m}^{2} \cdot \mathrm{g}^{-1}$ is composed of porous octahedral particles of $5-10 \mu \mathrm{m}$ in diameter. Methylene blue (MB) was utilized as the dye model for photocatalytic degradation reactions. The porous octahedral $\mathrm{ZnO} / \mathrm{CuO}$ exhibits superior visible-light-driven photocatalytic degradation of $\mathrm{MB}$ compared with single $\mathrm{CuO}$ or $\mathrm{ZnO}$. The kinetic model of photocatalytic degradation was proposed as $\left(1 / K_{\mathrm{L}}\right) \times \ln C+C=-k_{\mathrm{r}} t+\left(1 / K_{\mathrm{L}}\right) \times \ln C_{\mathrm{e}}+C_{\mathrm{e}}$, where $K_{\mathrm{L}}$ is the Langmuir equilibrium constant and $C_{\mathrm{e}}$ is the $\mathrm{MB}$ concentration at equilibrium. The model significantly fits the kinetic data. In addition, the acquired catalyst manifests excellent photocatalytic degradation for several other dyes including phenol red, methyl orange, and Congo red.
\end{abstract}

\section{Introduction}

Metal oxide semiconductors are widely used for photocatalytic degradation of organic pollutants due to their high photosensitivity, nontoxic nature, and low cost. It is well known that titanium oxide $\left(\mathrm{TiO}_{2}\right)$ and zinc oxide $(\mathrm{ZnO})$ can only be excited for photocatalysis. $\mathrm{ZnO}$ belongs to the $n$-type semiconductor and is considered one of the important semiconductor photocatalysts due to its high photosensitivity and stability $[1,2]$. However, the constraint of $\mathrm{ZnO}$ among others is that it absorbs light only in the near UV region because of its large bandwidth of $3.2 \mathrm{eV}$. Unfortunately, sunlight constitutes only $4-5 \%$ of UV light $[3,4]$. Therefore, the effective use of solar energy still remains a challenge in photocatalytic application. The photoresponse of narrowband-gap semiconductors shifts much more to the visible wavelength range. However, these semiconductors are difficult to maintain their photoactivity for a long time due to the recombination of the photo-induced electron-hole pairs. To improve the visible-light-driven photocatalytic efficiency of $\mathrm{ZnO}$, some metals or oxides are often introduced to its surface. $\mathrm{Au}$-loaded $\mathrm{ZnO}$ can significantly enhance the activities of photogenerated electrons by suppressing the recombination of charge carriers [5]. Unlike pure $\mathrm{ZnO}$, mesoporous $\mathrm{Fe}_{2} \mathrm{O}_{3} / \mathrm{ZnO}$ core-shell composites manifest an excellent photocatalytic degradation of Rhodamine B in both ultraviolet and visible light regions [6]. The nanostructure of cupric oxide $(\mathrm{CuO})$ is the $p$-type semiconductor with a narrow band gap of 1.2-2.71 eV. Despite its high capacity of absorption in the visible light range, $\mathrm{CuO}$ is surprisingly not appealing in terms of catalytic behavior due to its fast recombination rate of the induced electron-hole pairs. Thus, in order to 
achieve a high catalytic activity, a synergistic system may be expected by connecting $\mathrm{CuO}$ with $\mathrm{ZnO}$, in which $\mathrm{CuO}$ acts as a cocatalyst and thus expands the visiblelight response. Moreover, the possible formation of favorable $p-n$ junctions at the nanostructure interface restrains the photo-induced carrier recombination. Various approaches have been accomplished to synthesize $\mathrm{ZnO} / \mathrm{CuO}$ composites for photocatalytic application such as sol-gel and coprecipitation [7-9]. However, to achieve a high degree of homogeneous dispersion of each component still remains a major challenge with multimetal oxides.

Metal-organic frameworks (MOFs) are a class of crystalline materials that have coordination bonds between transition-metal cations and organic ligands. The metalorganic frameworks possess unique performance advantages, such as controllable pore size and pore surface, low density, and large surface area. These outstanding properties make MOFs widely used in many fields, for example, adsorption, photocatalysis, and biosensors [10-12]. HKUST-1 (Hong Kong University of Science and Technology) is one of the first MOFs made up of copper nodes with benzene-1,3,5tricarboxylic (BTC) acid struts between them [13]. HKUST1 (or MOF-199 or Cu-BTC) manifests remarkable potentials in photocatalysis [14, 15] and separation [16]. MOF-199 notably displays persistence in both water and air [13]. Zinc is a promising metal that constructs an isostructural analogue to Cu-BTC. Anbia et al. [17] reported the hydrothermal synthesis of Zn-BTC that can be a good material for hydrogen storage at room temperature. Zn-BTC is also synthesized through direct precipitation in solution under ultrasonic condition [18]. Xu et al. [19] reported the ionothermal synthesis of Zn-BTC using 1-ethyl-3-methylimidazolium bromide ionic liquid as a solvent. The use of ionic liquid in the synthesis of Zn-BTC has shown a vast range of possibilities of controlling the structures and obtaining new materials by tuning the properties of the ionic liquid. Zn-BTC possesses lower-than-expected surface areas (a few meters to a few dozen meters), or it completely collapses upon the removal of guest molecules [20]. Generally, synthetic conditions (temperature, atmosphere, and posttreatment) are critical to the formation of MOF diffractions as well as their physicochemical properties [17, 18, 21].

Multimetal component MOFs have widely been synthesized by simultaneously mixing several metal species with organic ligands $[22,23]$. There exist several advantages of using multimetal-component MOFs as sacrificial templates compared with other conventional templates [24]. They are as follows:

(i) The metal species in MOFs are mixed at molecular levels

(ii) Homogeneous morphologies of MOFs are critical regarding the preparation of anisotropic multimetal oxides that are difficult to fabricate using classical methods

(iii) Undesired aggregation or structural collapse of the framework during thermolysis can be minimized due to their structural strength
$\mathrm{Xu}$ et al. successfully synthesized hierarchical porous $\mathrm{ZnO} / \mathrm{ZnCo}_{2} \mathrm{O}_{4}$ using one-step thermal calcining the asprepared $\mathrm{Zn}$-Co-MOF precursor [25]. Huang et al. reported hierarchical $\mathrm{NiFe}_{2} \mathrm{O}_{4} / \mathrm{Fe}_{2} \mathrm{O}_{3}$ nanotubes prepared from MOFs for superior lithium-ion batteries [26]. Wu et al. developed a facile method for the synthesis of a hybrid $\mathrm{Zn}_{x} \mathrm{Co}_{(3-x)} \mathrm{O}_{4}$ composite via the thermal oxidative decomposition of bimetallic ( $\mathrm{Zn} / \mathrm{Co})$ zeolitic imidazolate frameworks (ZIFs) [27]. Recently, Lei et al. demonstrated the hollow $\mathrm{CuO} / \mathrm{ZnO}$ materials derived from zeolite imidazole framework-8. This material is a very promising photocatalyst for tetracycline degradation [28]. However, so far, little work has been carried out to prepare $\mathrm{ZnO} / \mathrm{CuO}$ from MOFs.

In the present paper, a porous octahedral $(\mathrm{ZnO} / \mathrm{CuO})$ composite is synthesized from zinc/copper-based metalorganic framework-199, and its applications in visible-lightdriven photocatalytic degradation of dyes are demonstrated. The precursors of $\mathrm{Zn}-\mathrm{BTC}, \mathrm{Cu}-\mathrm{BTC}$, and $\mathrm{Zn} / \mathrm{Cu}-\mathrm{BTC}$ are synthesized with a microwave-assisted method. In addition, pure Zn-BTC and Cu-BTC are prepared for the sake of comparison. Benzene-1,3,5-tricarboxylic acts as a sacrificial template and is removed by calcination. The kinetic model of photocatalytic degradation is proposed by combining the heterogeneous catalysis for unimolecular reactions with adsorption isotherms.

\section{Experimental}

2.1. Materials. Benzene-1,3,5-tricarboxylic acid $\left(\mathrm{C}_{6} \mathrm{H}_{3}\right.$ $(\mathrm{COOH})_{3}, \geq 95 \%$ ) (denoted as $\mathrm{BTC}$ ), copper nitrate trihydrate $\left(\mathrm{Cu}\left(\mathrm{NO}_{3}\right)_{2} \cdot 3 \mathrm{H}_{2} \mathrm{O}, 99.5 \%\right)$, zinc nitrate tetrahydrate $\left(\mathrm{Zn}\left(\mathrm{NO}_{3}\right)_{2} \cdot 4 \mathrm{H}_{2} \mathrm{O}, 98.5 \%\right)$, methyl orange $\left(\mathrm{C}_{14} \mathrm{H}_{14} \mathrm{~N}_{3} \mathrm{NaO}_{3} \mathrm{~S}\right.$, $85 \%)$, phenol red $\left(\mathrm{C}_{19} \mathrm{H}_{14} \mathrm{O}_{5} \mathrm{~S}, 90 \%\right)$, and Congo red $\left(\mathrm{C}_{32} \mathrm{H}_{22} \mathrm{~N}_{6} \mathrm{Na}_{2} \mathrm{O}_{6} \mathrm{~S}_{2}, 85 \%\right)$, potassium iodide (KI, 99\%), benzoquinone $\left(\mathrm{C}_{6} \mathrm{H}_{4} \mathrm{O}_{2}, 98 \%\right)$, and isopropanol $\left(\mathrm{C}_{3} \mathrm{H}_{7} \mathrm{OH}\right)$ were purchased from Merck, Germany. Dimethylformamide $\left(\left(\mathrm{CH}_{3}\right)_{2} \mathrm{NCHO}\right)$, ethanol $\left(\mathrm{C}_{2} \mathrm{H}_{5} \mathrm{OH}\right)$, methanol $\left(\mathrm{CH}_{3} \mathrm{OH}\right.$, $99 \%$ purity), and methylene blue $\left(\mathrm{C}_{16} \mathrm{H}_{18} \mathrm{ClN}_{3} \mathrm{~S}, 82 \%-\mathrm{MB}\right)$ were acquired from HiMedia, India. Methylene blue is used as the dye model. Potassium iodide and benzoquinone are used as scavengers in the current study.

2.2. Apparatus. Powder X-ray diffraction patterns (PXRD) were performed on a D8 Advance Bruker monochromator equipped with a $\mathrm{Cu}-\mathrm{K} \alpha$ radiation source $(\lambda=1.5406 \AA)$. The morphologies of the obtained samples were analyzed using a scanning electron microscope (SEM) (Hitachi S$4800)$ and a high-resolution transmission electron microscope (HR-TEM) (JEM-2100). Thermo analysis (TG-DTA) was carried out using a TG-DTA instrument (DTG-60H Shimadzu) under atmospheric pressure at a heating rate of $10^{\circ} \mathrm{C} \cdot \mathrm{min}^{-1}$. Nitrogen adsorption/desorption isotherms were recorded on a Micromeritics ASAP 2020 instrument. The samples $(200 \mathrm{mg})$ were degassed at $120^{\circ} \mathrm{C}$ for $24 \mathrm{~h}$ before measurements. The specific surface area was determined via the Brunauer-Emmett-Teller (BET) model with a relative pressure of 0.01-0.25 using adsorption data. Pore size distribution calculation was accomplished with the BJH (Barrett, Joyner, and Halenda) model using the adsorption branch of 
the isotherms. The data of ultraviolet-visible diffuse reflectance spectroscopy (UV-Vis-DRS) were recorded on a Cary $5000 \mathrm{UV}$-Vis spectrometer (using $\mathrm{BaSO}_{4}$ as the reference) at a collection speed of $600 \mathrm{~nm} \cdot \mathrm{min}^{-1}$. X-ray photoelectron spectroscopy (XPS) was recorded with a Kratos Analytical spectrometer. All binding energies were referenced to the contaminant $\mathrm{C}$ 1s peak (at $284.6 \mathrm{eV}$ ) of adventitious carbon. The elemental compositions of $\mathrm{Zn}$ and $\mathrm{Cu}$ were analyzed with atomic absorption spectroscopy (AAS) using ZEEnit 7000. The elemental analysis of $\mathrm{C}$ and $\mathrm{H}$ was performed using Elemental Analyzer EA3000. Photoluminescence spectra of the obtained materials were measured at room temperature with a photoluminescence spectrophotometer (Horiba FL3). The concentration of dyes was measured using a UV-Vis spectrophotometer (V-630 Jasco) at $\lambda_{\max } 644 \mathrm{~nm}$ for methylene blue, $464 \mathrm{~nm}$ for methyl orange, $431 \mathrm{~nm}$ for phenol red, $500 \mathrm{~nm}$ for Congo red, and $270 \mathrm{~nm}$ for phenol. The degree of MB mineralization was calculated based on TOC (total organic carbon). The concentration of TOC was determined using a TOC analyzer (TOC- $\left.\mathrm{V}_{\mathrm{CPH}}\right)$.

2.3. Preparation of $\mathrm{Zn} / \mathrm{Cu}-\mathrm{BTC}$, $\mathrm{Cu}-\mathrm{BTC}, \mathrm{Zn}-\mathrm{BTC}, \mathrm{ZnO} / \mathrm{CuO}$, $\mathrm{CuO}$, and $\mathrm{ZnO}$. Benzene-1,3,5-tricarboxylic acid $(0.4410 \mathrm{~g}$, $0.0021 \mathrm{~mol}), \mathrm{Cu}\left(\mathrm{NO}_{3}\right)_{2} \cdot 3 \mathrm{H}_{2} \mathrm{O}(0.2289 \mathrm{~g}, 0.00095 \mathrm{~mol})$, and $\mathrm{Zn}\left(\mathrm{NO}_{3}\right)_{2} \cdot 4 \mathrm{H}_{2} \mathrm{O}(0.5757 \mathrm{~g}, 0.0022 \mathrm{~mol})$ were first dissolved in a mixture $(21 \mathrm{~mL})$ of ethanol, distilled water, and dimethylformamide $(1: 1: 1$ in $v / v)$ and stirred magnetically for $5 \mathrm{~min}$. The resultant mixture was then loaded into a $250 \mathrm{~mL}$ Erlenmeyer flask and placed in a hand-made microwave device (Sharp R-203VN-M with a power of $250 \mathrm{~W}$ ) [29] and irradiated for $30 \mathrm{~min}$. The solid was collected by centrifugation, washed with DMF three times, dried at $180^{\circ} \mathrm{C}$ for $8 \mathrm{~h}$, and designated as Zn/Cu-BTC [29]. Zn-BTC and $\mathrm{Cu}-\mathrm{BTC}$ were synthesized with the same procedure. Oxides $(\mathrm{ZnO} / \mathrm{CuO}, \mathrm{ZnO}$, and $\mathrm{CuO})$ were prepared by annealing $\mathrm{Zn} / \mathrm{Cu}-\mathrm{BTC}, \mathrm{Zn}-\mathrm{BTC}$, and $\mathrm{Cu}-\mathrm{BTC}$ at $500^{\circ} \mathrm{C}$ for $5 \mathrm{~h}$ at a heating rate of $5^{\circ} \mathrm{C} \cdot \mathrm{min}^{-1}$ under atmospheric pressure in an electric furnace (Vulcan 3-550 PD). The oxides were stored in a desiccator and used as a catalyst without any further treatment.

\subsection{Photocatalytic Activity}

2.4.1. Photocatalytic Performance. A beaker containing $500 \mathrm{~mL}$ of an aqueous suspension of $\mathrm{MB}(5-30 \mathrm{ppm})$ and $400 \mathrm{mg}$ of catalyst was placed under a lamp bracket. The light source is a $160 \mathrm{~W}$ metal halide lamp (Philips) equipped with a wavelength cut-off filter $(\lambda \leq 420 \mathrm{~nm}$ ) (or Philips, Actinic BL $18 \mathrm{~W}, \lambda=365 \mathrm{~nm}$ ). Prior to illumination, the suspension was stirred magnetically in the dark for $60-180 \mathrm{~min}$ to ensure adsorption equilibrium. Three millilitres of the suspension was withdrawn at a certain time interval and centrifuged to remove the solid catalyst. The concentration of $\mathrm{MB}$ in the obtained clear liquid was analyzed using a UV-Vis spectrophotometer at $\lambda=664 \mathrm{~nm}$. Further, the concentration of MB during illumination was determined using the aforesaid steps. In the scavenging test, potassium iodide, benzoquinone, and isopropanol were used as scavengers. A suspension of $100 \mathrm{~mL} \mathrm{MB} \mathrm{(10} \mathrm{ppm)} \mathrm{and} 80 \mathrm{mg}$ catalyst was first stirred in the dark, and $1 \mathrm{~mL}$ of the scavenger solution $\left(2.4 \times 10^{-2} \mathrm{M}\right)$ was then added to the mixture under illumination.

2.4.2. Kinetic Analysis. The photocatalytic dye degradation kinetic is often investigated according to the pseudo-firstorder kinetic model or the Langmuir-Hinshelwood model $[30,31]$ for heterogeneous catalysis as follows:

$$
\ln \frac{C}{C_{0}}=-k \cdot t,
$$

where $C_{0}$ and $C$ are the initial concentration at time $t\left(\mathrm{mg} \cdot \mathrm{L}^{-1}\right)$ and $k$ is the rate constant $\left(\mathrm{min}^{-1}\right)$.

However, the experimental design often involves two consecutive steps of dark adsorption and photocatalytic degradation. The problem to discuss here is the concentration $C_{0}$ in equation (1): whether it is the initial concentration or the equilibrium concentration just before illumination $\left(C_{\mathrm{e}}\right)$. Both of them seem unreasonable because $C_{\mathrm{e}}$, in this case, is not an independent variable, but it depends on the balance of the dye in the solution and the adsorbent. $C_{0}$ is the initial concentration. However, as soon as the photocatalytic reaction occurs, the initial concentration is not $C_{0}$ but $C_{\mathrm{e}}$. Most studies have ignored this issue. In order to overcome this obstacle, a new kinetic model is proposed by combining the heterogeneous catalysis for unimolecular reactions with the adsorption isotherms.

A heterogeneous catalyst first adsorbs the dye molecule from the aqueous solution onto its surface and then catalyzes the reaction under irradiation (two steps).

Step 1: adsorption

$$
\text { Dye }+ \text { surface } \longleftrightarrow \text { dye }(\text { adsorbed })(\text { fast })
$$

Step 2: photocatalytic reaction

$$
\text { Dye(adsorbed) } \longrightarrow \text { products(slow) }
$$

It can be assumed that the first step occurs until equilibrium, whereas the second is rate limiting.

For the first step, the equilibrium adsorption capacity $q_{\mathrm{e}}\left(\mathrm{mg}^{\mathrm{g}} \mathrm{g}^{-1}\right)$ can be calculated according to

$$
q_{\mathrm{e}}=V \cdot \frac{C_{0}-C_{e}}{m},
$$

where $C_{0}$ and $C_{\mathrm{e}}$ are the initial and equilibrium dye concentrations $\left(\mathrm{mg} \cdot \mathrm{L}^{-1}\right) ; V$ and $m$ are the solution volume (L) and mass of catalyst (g), respectively.

Further, $C_{\mathrm{e}}$ and $q_{\mathrm{e}}$ are related following the Langmuir isotherm.

$$
q_{\mathrm{e}}=q_{\mathrm{m}} \cdot \frac{K_{\mathrm{L}} \cdot C_{\mathrm{e}}}{1+K_{\mathrm{L}} \cdot C_{\mathrm{e}}},
$$


where $q_{\mathrm{m}}\left(\mathrm{mg}^{-1} \mathrm{~g}^{-1}\right)$ and $K_{\mathrm{L}}\left(\mathrm{L} \cdot \mathrm{mg}^{-1}\right)$ are the maximum monolayer adsorption capacity and the Langmuir equilibrium constant, respectively.

The photocatalytic degradation rate can be expressed by

$$
r=k_{\mathrm{r}} \cdot \theta,
$$

where $k_{\mathrm{r}}$ is the apparent rate constant $\left(\mathrm{mg} \cdot \mathrm{L}^{-1} \cdot \mathrm{min}^{-1}\right)$ and $\theta$ is the coverage fraction (dimensionless), which can be represented by the Langmuir isotherm. Therefore, equation (6) can be rewritten as

$$
r=k_{\mathrm{r}} \cdot \frac{K_{\mathrm{L}} \cdot C}{1+K_{\mathrm{L}} \cdot C}=-\frac{d C}{d t} .
$$

Now, integrating equation (7) with the boundary conditions of $C=C_{\mathrm{e}}$ at $t=0 \mathrm{~min}$ (subtracted the time required for saturated adsorption) and $C=C$ at $t=t$.

$$
\frac{1}{K_{\mathrm{L}}} \cdot \ln C+C=-k_{\mathrm{r}} \cdot t+\frac{1}{K_{\mathrm{L}}} \cdot \ln C_{\mathrm{e}}+C_{\mathrm{e}} .
$$

The values of $k_{\mathrm{r}}$ can be obtained from the slope of the linear plot $\left(\left(1 / K_{L}\right) \cdot \ln C+C\right)$ vs. $t$.

\section{Results and Discussion}

3.1. Synthesis of the Porous Octahedral $\mathrm{ZnO} / \mathrm{CuO}$ Composite from $\mathrm{Zn} / \mathrm{Cu}$-BTC. The compositional phase of the asprepared materials is investigated using XRD (Figure 1). The reflection peaks of Cu-BTC appear as (200), (220), (311), (222), (400), (331), (420), (422), (511), (440), (600), (444), (511), (553), and (751) [32,33], which indicates that the obtained $\mathrm{Cu}-\mathrm{BTC}$ is MOF-199 with a space group of $F m \overline{3} m$ [13]. Zn-BTC can exist in different forms depending on the synthesis conditions. The XRD pattern of the prepared $\mathrm{Zn}$-BTC is consistent with that of Zn-BTC synthesized with the microwave-assisted method [21] but is different from that synthesized from $\mathrm{Zn}\left(\mathrm{CH}_{3} \mathrm{COO}\right)$ with the solvothermal method [17] and with the ultrasound-assisted method [18]. The XRD patterns of $\mathrm{Zn} / \mathrm{Cu}-\mathrm{BTC}$ are consistent with those of $\mathrm{Cu}$-BTC with a characteristic peak of $\mathrm{Zn-BTC}$ at $10.5^{\circ}$, indicating that $\mathrm{Zn} / \mathrm{Cu}-\mathrm{BTC}$ is constituted from $\mathrm{Cu}-\mathrm{BTC}$ and Zn-BTC.

The thermal behaviors of BTC compounds are studied via TG-DTA (Figure 2). For Zn-BTC and Cu-BTC, an exothermic peak appears at around 472 and $327^{\circ} \mathrm{C}$, respectively, accompanied by large weight losses (approximately 42 and $39 \%$ ), which is attributed to the combustion of BTC in the compounds (see Table S1). The complete decomposition temperature is around $470^{\circ} \mathrm{C}$ for $\mathrm{Cu}-\mathrm{BTC}\left(400^{\circ} \mathrm{C}\right.$ reported by reference [34], $670^{\circ} \mathrm{C}$ reported by reference [35]) and $500^{\circ} \mathrm{C}$ for $\mathrm{Zn}-\mathrm{BTC}$. In the case of $\mathrm{Zn} / \mathrm{Cu}-\mathrm{BTC}$, an endothermic peak at $100^{\circ} \mathrm{C}$ with a weight loss of approximately $27 \%$ is assigned to the evaporation of the physically adsorbed water. Two exothermic peaks at 334 and $387^{\circ} \mathrm{C}$ with a weight loss of around $47 \%$ are due to the decomposition of $\mathrm{Cu}-\mathrm{BTC}$ and $\mathrm{Zn}-\mathrm{BTC}$ in $\mathrm{Zn} / \mathrm{Cu}-\mathrm{BTC}$. The complete decomposition of $\mathrm{Zn} / \mathrm{Cu}-\mathrm{BTC}$ also takes place at around $500^{\circ} \mathrm{C}$, and

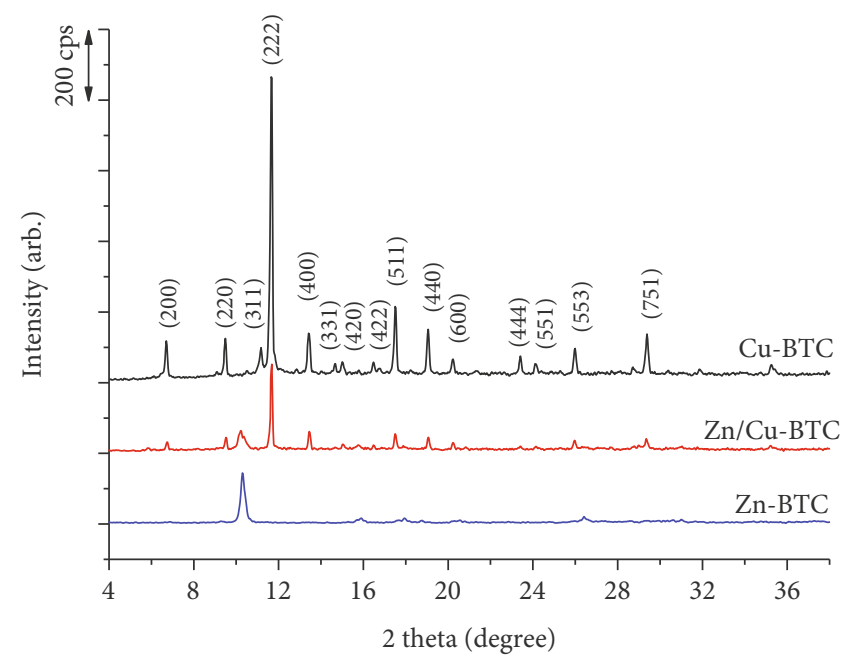

Figure 1: XRD patterns of Cu-BTC, Zn-BTC, and Zn/Cu-BTC.

therefore, this temperature is selected to calcinate the precursors to obtain the oxides.

During the calcination for 5 hours, hexagonal wurtzite $\mathrm{ZnO}$, monoclinic $\mathrm{CuO}$ (JCPDS card No. 48-1548 and 361451, respectively), and bimetallic $\mathrm{ZnO} / \mathrm{CuO}$ are formed (Figure 3). No unknown peaks are observed in the XRD diagrams, indicating that pure single oxides and a bimetallic oxide $(\mathrm{ZnO} / \mathrm{CuO})$ are obtained. In addition, the presence of peak broadening reveals that a grain refinement occurs in $\mathrm{ZnO} / \mathrm{CuO}$ possibly due to the formation of heterojunction structures. The average particle size of $\mathrm{ZnO}$ and $\mathrm{CuO}$ in the octahedral $\mathrm{ZnO} / \mathrm{CuO}$ nanocomposite is $\sim 44 \mathrm{~nm}$ and $\sim 23 \mathrm{~nm}$ (calculated using Scherrer's equation from the line broadening of (101) and (111) diffraction peak for $\mathrm{ZnO}$ and $\mathrm{CuO}$, respectively).

Figure 4 displays the morphologies of the as-prepared materials before and after calcination. Cu-BTC yields smooth octahedral crystals of $\sim 10 \mu \mathrm{m}$ size (Figure 4(a1)); however, during calcination, the structural framework of $\mathrm{Cu}-\mathrm{BTC}$ collapses to form irregular particles (Figure 4(a2)). To prevent this collapse, the calcination temperature was set to $\sim 400^{\circ} \mathrm{C}$ (Figure S1). Zn-BTC comprises nanorods of diameter $\sim 200 \mathrm{~nm}$ (Figure 4(b1)), and after calcination, they yield in $\mathrm{ZnO}$ nanofibers (consisted of nanoparticles of $30 \sim 50 \mathrm{~nm}$ size) (Figure 4(b2)). As for $\mathrm{Zn} / \mathrm{Cu}-\mathrm{BTC}$, octahedral particles with flocculent substances (Zn-BTC) on the crystal surface are formed (Figure 4(c1)). Bimetallic $\mathrm{ZnO} / \mathrm{CuO}$ octahedrons of diameter $5-10 \mu \mathrm{m}$ remain unaltered after calcination (Figure 4(c2)). The TEM images show that $\mathrm{ZnO} / \mathrm{CuO}$ octahedrons comprise nanoparticles of $\sim 50 \mathrm{~nm}$ size (Figure $4(\mathrm{~d} 1)$ ). On the HR-TEM images of $\mathrm{ZnO} / \mathrm{CuO}$, it can be seen that the interplanar spacing of lattice fringes is $0.232 \mathrm{~nm}$ (corresponding to the (111) plane of monoclinic CuO (JCPDS card No. 48-1548)) and $0.281 \mathrm{~nm}$ (corresponding to the (100) plane of hexagonal $\mathrm{ZnO}$ (JCPDS card No. 36-1451)). Hence, the intragranular location of both oxide phases could enhance the efficiency of semiconductor coupling effects. 


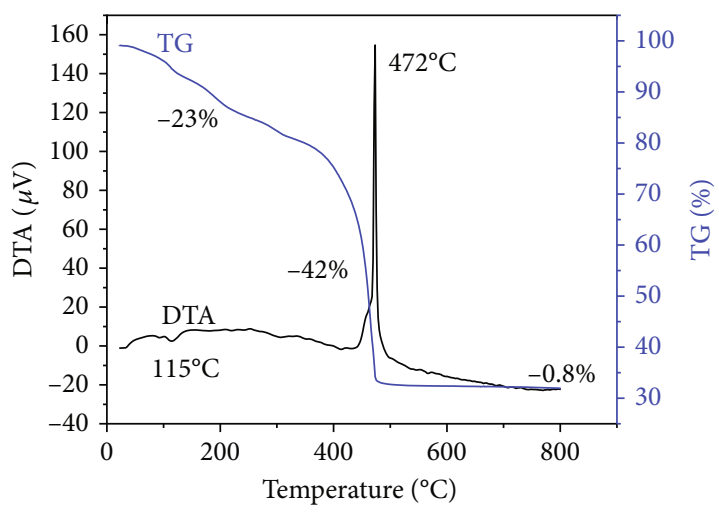

(a)

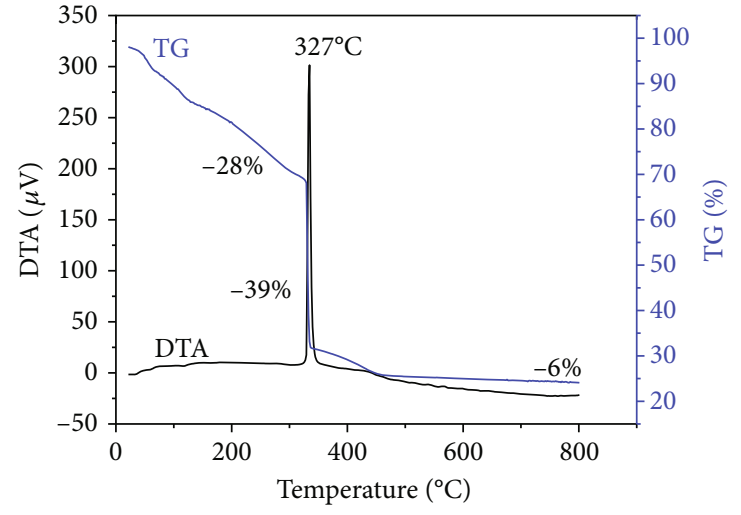

(b)

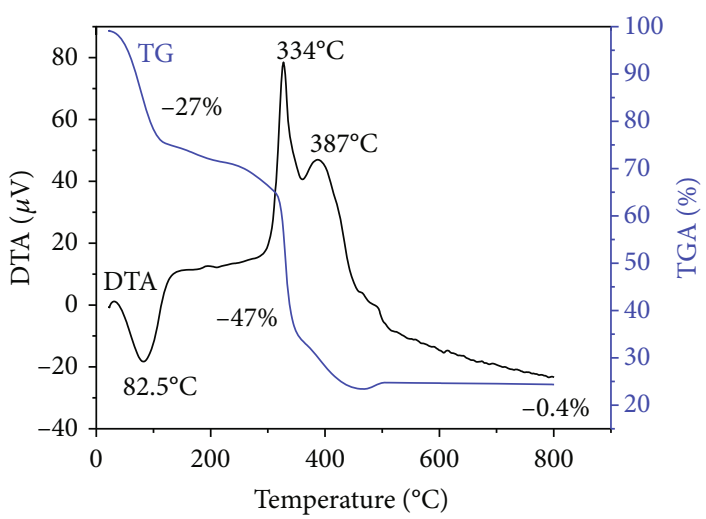

(c)

Figure 2: TG-DTA diagrams of (a) Zn-BTC, (b) Cu-BTC, and (c) Zn/Cu-BTC.

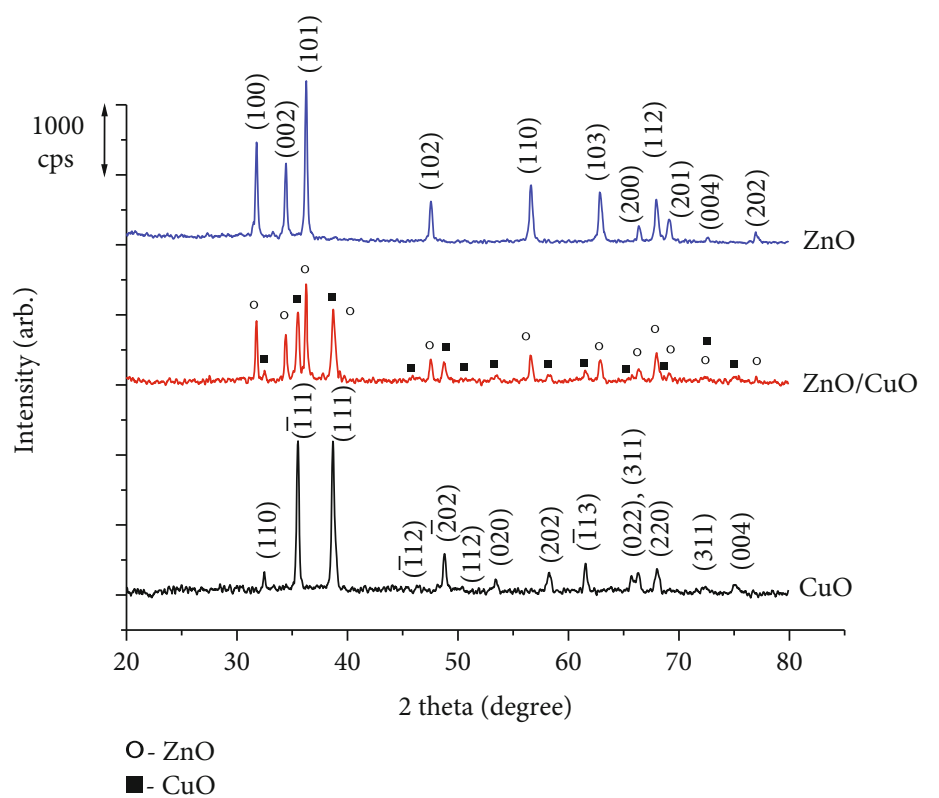

Figure 3: XRD patterns of $\mathrm{ZnO}, \mathrm{CuO}$, and $\mathrm{ZnO} / \mathrm{CuO}$.

The elemental analysis of $\mathrm{C}, \mathrm{H}, \mathrm{Zn}$, and $\mathrm{Cu}$ in the as-prepared materials is presented in Table 1. No carbon is present in $\mathrm{ZnO} / \mathrm{CuO}$, indicating the complete removal of the organic templates. The molar ratio of $\mathrm{Zn} / \mathrm{Cu}$ in $\mathrm{Zn} / \mathrm{Cu}-\mathrm{BTC}$ and $\mathrm{ZnO} / \mathrm{CuO}$ analyzed with $\mathrm{AAS}$ and $\mathrm{EDX}$ (Figure S2) is practically identical $(0.42 / 1$ and $0.39 / 1$ for 

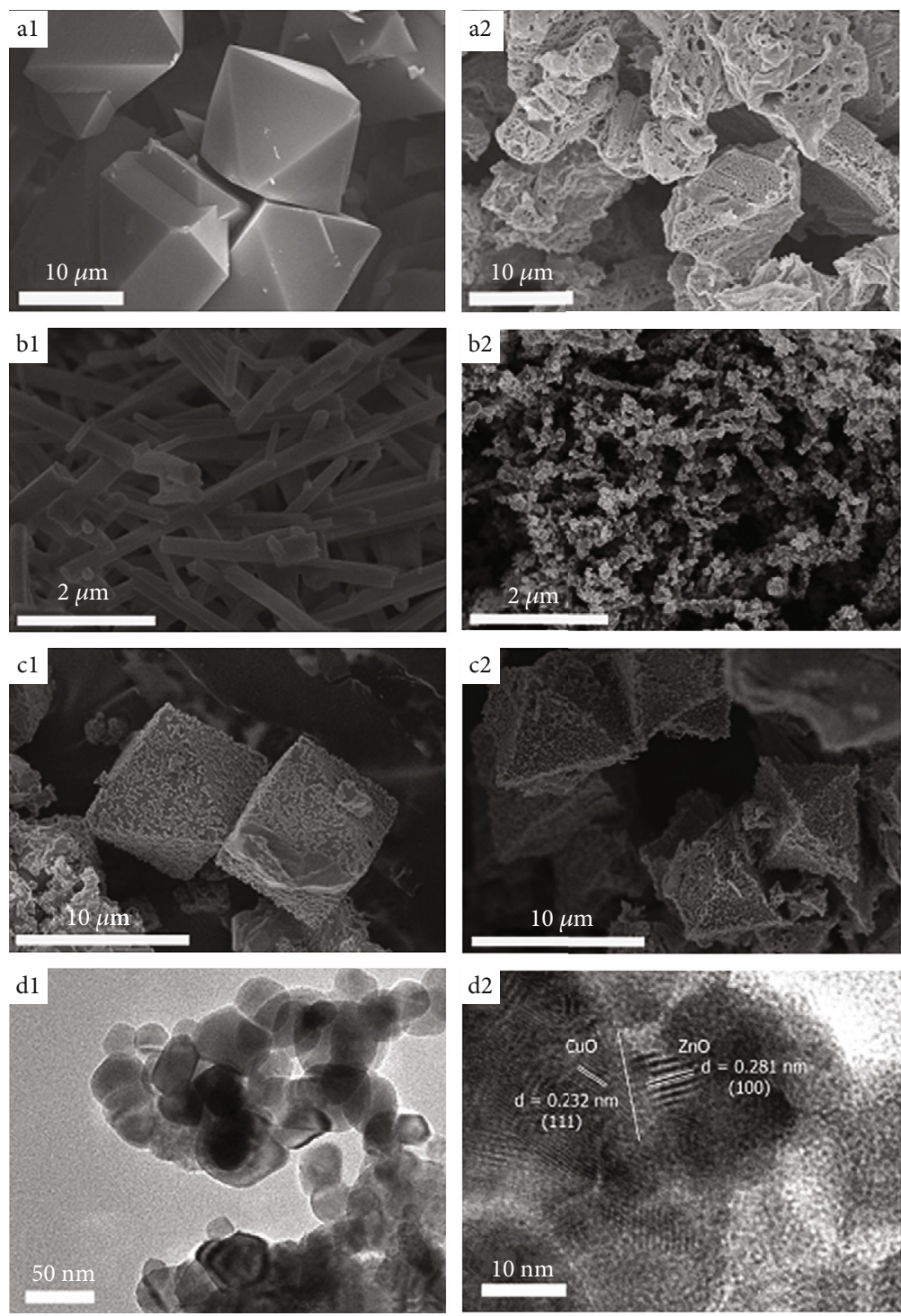

Figure 4: SEM observations of (a1) Cu-BTC, (b1) Zn-BTC, (c1) Zn/Cu-BTC, (a2) CuO, (b2) ZnO, and (c2) ZnO/CuO; (d1) TEM observation of $\mathrm{ZnO} / \mathrm{CuO}$; (d2) HR-TEM of $\mathrm{ZnO}$ and $\mathrm{CuO}$ region.

Table 1: Elemental analysis of $\mathrm{C}, \mathrm{H}, \mathrm{Zn}$, and $\mathrm{Cu}$ in $\mathrm{Zn} / \mathrm{Cu}-\mathrm{BTC}$ and $\mathrm{ZnO} / \mathrm{CuO}$.

\begin{tabular}{lcccccc}
\hline \multirow{2}{*}{ Notation } & \multicolumn{3}{c}{$\begin{array}{c}\text { Elemental composition } \\
\text { (\% mass) }\end{array}$} & \multicolumn{2}{c}{$\begin{array}{c}\text { Zn/Cu } \\
(\mathrm{mol} / \mathrm{mol})\end{array}$} \\
& $\mathrm{C}^{*}$ & $\mathrm{H}^{*}$ & $\mathrm{Zn}^{* *}$ & $\mathrm{Cu}^{* *}$ & $\left({ }^{* *}\right)$ & $\left(^{* *}\right)$ \\
\hline $\mathrm{Zn} / \mathrm{Cu}-\mathrm{BTC}$ & 36.18 & 1.93 & 7.49 & 17.19 & $0.42 / 1$ & $0.39 / 1$ \\
$\mathrm{ZnO} / \mathrm{CuO}$ & 0.00 & 0.00 & 20.18 & 62.56 & $0.31 / 1$ & $0.30 / 1$ \\
\hline
\end{tabular}

${ }^{*}$ Elemental analysis; ${ }^{* *}$ AAS analysis; ${ }^{* * *}$ EDX analysis.

$\mathrm{Zn} / \mathrm{Cu}-\mathrm{BTC}$ and $0.31 / 1$ and $0.30 / 1$ for $\mathrm{ZnO} / \mathrm{CuO}$ ), implying a high dispersion of bimetallic oxides. However, this molar ratio is significantly lower than the initial one $(\mathrm{Zn} / \mathrm{Cu}=7 / 3=2.33 / 1)$, signifying that a large number of $\mathrm{Zn}^{2+}$ ions remain in the solution instead of transforming into $\mathrm{ZnO}$. It might happen due to the lower affinity of
Zn (electronegativity, 1.65) to carboxyl groups in BTC compared with that of $\mathrm{Cu}$ to BTC (electronegativity, 1.9).

The textural properties of the as-synthesized materials were investigated using nitrogen adsorption/desorption isotherms (Figure 5). According to IUPAC, the obtained BTC compounds can be assigned to I-type (microporous materials) [36, 37]. BTC compounds except Zn-BTC exhibit a large surface area as those published in the literature [13]. The BET surface areas of $\mathrm{Cu}-\mathrm{BTC}, \mathrm{Zn}-\mathrm{BTC}$, and $\mathrm{Zn} / \mathrm{Cu}-$ BTC are $1635 \mathrm{~m}^{2} \cdot \mathrm{g}^{-1}, 3 \mathrm{~m}^{2} \cdot \mathrm{g}^{-1}$, and $844.4 \mathrm{~m}^{2} \cdot \mathrm{g}^{-1}$, respectively (see Table S2). Feldblyum et al. [20] asserted that the low surface area of Zn-BTC is because of its densified surface crystal, presumably due to pore collapse. The blocking of large pores at the surface effectively inhibits adsorbates such as $\mathrm{N}_{2}$ gas from entering the bulk structure [20]. After calcination, the isotherm of $\mathrm{ZnO}$ remains in type $\mathrm{I}$, while the other oxides exhibit the type-IV isotherm with an $\mathrm{H} 3$ 




(a)

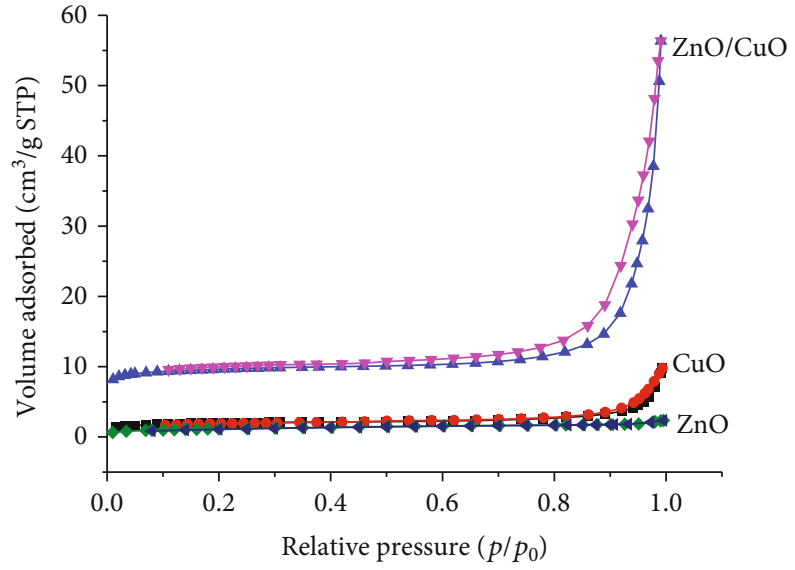

(b)

FIgURE 5: Nitrogen adsorption/desorption isotherms of $\mathrm{Cu}-\mathrm{BTC}, \mathrm{Zn}-\mathrm{BTC}, \mathrm{Zn} / \mathrm{Cu}-\mathrm{BTC}, \mathrm{CuO}, \mathrm{ZnO}$, and $\mathrm{ZnO} / \mathrm{CuO}$.

hysteresis loop at a relative pressure ranging from 0.5 to 0.9 , manifesting the presence of mesopores and micropores $[36,38]$. The specific surface area of calcined materials except $\mathrm{ZnO}$ reduces significantly to $6.7 \mathrm{~m}^{2} \cdot \mathrm{g}^{-1}$ for $\mathrm{CuO}$ and $32.5 \mathrm{~m}^{2} \cdot \mathrm{g}^{-1}$ for $\mathrm{ZnO} / \mathrm{CuO}$. It is worth noting that the specific surface area of the octahedral $\mathrm{ZnO} / \mathrm{CuO}$ nanocomposite in this study is significantly higher than that of $\mathrm{ZnO}$ and $\mathrm{CuO}$ and approximately two to four times as high as that of several $\mathrm{ZnO} / \mathrm{CuO}$ composites synthesized with other methods $[7,39,40]$. This result confirms the advantages of synthesizing multimetal oxide from MOF precursors.

The XPS spectra of the $\mathrm{ZnO} / \mathrm{CuO}$ nanocomposite are presented in Figure 6 . The survey spectrum shows that the presence of $\mathrm{Zn}, \mathrm{Cu}$, and $\mathrm{O}$ without any foreign species except for carbon whose 1 s peak $(284 \mathrm{eV})$ is employed to calibrate the acquired spectra (Figure 6(a)). The XPS spectrum of $\mathrm{Cu}$ has a doublet of $\mathrm{Cu} 2 \mathrm{p}_{3 / 2}$ (at $933 \mathrm{eV}$ ) and $\mathrm{Cu} 2 \mathrm{p}_{1 / 2}$ (at $952 \mathrm{eV}$ ) along with other satellite peaks at higher binding energies [39] (Figure 6(b)). Both peaks are very typical for the XPS spectrum of $\mathrm{Cu}^{2+}$ [28]. $\mathrm{Zn}$ (II) manifests a doublet of $\mathrm{Zn} 2 \mathrm{p}_{3 / 2}$ at $1022 \mathrm{eV}$ and $\mathrm{Zn} 2 \mathrm{p}_{1 / 2}$ at $1045 \mathrm{eV}$ (Figure 6(c)) [41]. Therefore, it can be inferred that $\mathrm{ZnO} / \mathrm{CuO}$ is a compound containing $\mathrm{Zn}$ (II), $\mathrm{Cu}$ (II), and $\mathrm{O}$.

The band gap energies $\left(E_{\mathrm{g}}\right)$ of $\mathrm{ZnO}, \mathrm{CuO}$, and $\mathrm{ZnO} / \mathrm{CuO}$ are calculated using UV-Vis-DRS measured at room temperature (Figure $7(\mathrm{a})$ ). $\mathrm{ZnO}$ exhibits an absorption band with wavelengths of $350-390 \mathrm{~nm}$ (band gaps of 3.5-3.2 eV) in the ultraviolet region. $\mathrm{CuO}$ manifests a broad peak in the visible light region. The characteristic absorption bands of $\mathrm{ZnO}$ and $\mathrm{CuO}$ are observed in the spectrum of $\mathrm{ZnO} / \mathrm{CuO}$. The absorption band of $\mathrm{CuO}$ shifts toward shorter wavelengths and integrates with the absorption band of $\mathrm{ZnO}$, signifying that the band edges of $p$-type $\mathrm{CuO}$ and $n$-type $\mathrm{ZnO}$ are wellmatched [8]. Tauc's plot [42] is illustrated in Figure 7(b). The $E_{\mathrm{g}}$ values of $\mathrm{ZnO}$ and $\mathrm{CuO}$ are $3.19 \mathrm{eV}$ and $1.94 \mathrm{eV}$, respectively (previously reported as $3.2-3.3 \mathrm{eV}$ for $\mathrm{ZnO}$ $[43,44]$ and $1.4-1.85 \mathrm{eV}$ for $\mathrm{CuO}[44-46]$ ) (see Table S3).
$\mathrm{ZnO} / \mathrm{CuO}$ has an $E_{\mathrm{g}}$ value of $2.63 \mathrm{eV}$, manifesting a remarkable shift toward the longer wavelength region.

Figure 8 shows the photoluminescence spectra (PL) of the obtained materials with an excitation wavelength of $300 \mathrm{~nm}$. The maximum PL intensity is at $387.4 \mathrm{~nm}$ for $\mathrm{CuO}$ and $510.2 \mathrm{~nm}$ for $\mathrm{ZnO}$. However, the PL intensity of $\mathrm{ZnO} / \mathrm{CuO}$ composite is significantly weaker than those of the $\mathrm{CuO}$ and $\mathrm{ZnO}$. It is well known that low PL intensity means low recombination of electron and holes, then the opposite would be high PL intensity would increase recombination rate and reduce photocatalytic activity. These results demonstrate that the combinations $\mathrm{ZnO}$ and $\mathrm{CuO}$ have reduced the recombination of photonic electrons and photogenic holes, which may increase the photocatalytic activity of the material.

\subsection{Visible-Light-Driven Photocatalytic Degradation of Dyes}

3.2.1. Decolorization of MB with Different Catalysts. Figure 9(a) displays the process of $\mathrm{MB}$ decolorization over Zn-BTC, $\mathrm{Cu}-\mathrm{BTC}$, and $\mathrm{Zn} / \mathrm{Cu}-\mathrm{BTC}$. It is apparent that the adsorption equilibrium is reached after $60 \mathrm{~min}$, and the BTC compounds exhibit high adsorption capacities. $\mathrm{Zn} / \mathrm{Cu}-$ BTC displays the highest decolorization efficiency $(F)$ at $\sim 69 \%$, followed by Cu-BTC ( 66\%) and Zn-BTC ( 22\%) $\left(F=100 \times\left(C_{0}-C_{\mathrm{t}}\right) / C_{0}\right.$, where $C_{0}$ and $C_{\mathrm{t}}$ are the initial concentration and at time $t$ ). However, the decolorization efficiency of Cu-BTC decreases to $41-50 \%$ after $60 \mathrm{~min}$ of UV/Vis irradiation. This indicates that desorption occurs during irradiation. Zn-BTC exhibits weak photocatalytic activity upon UV or Vis irradiation and yields a decolorization efficiency of $\sim 50 \%$ after $420 \mathrm{~min}$ of UV illumination and $38 \%$ after $420 \mathrm{~min}$ of Vis irradiation. This may be due to its very low surface area which decreases the number of active sites for $\mathrm{MB}$ to adsorb and decompose.

In contrast, all calcinated materials manifest poor adsorption with a very low decolorization efficiency of $\sim 5 \%$. This is 


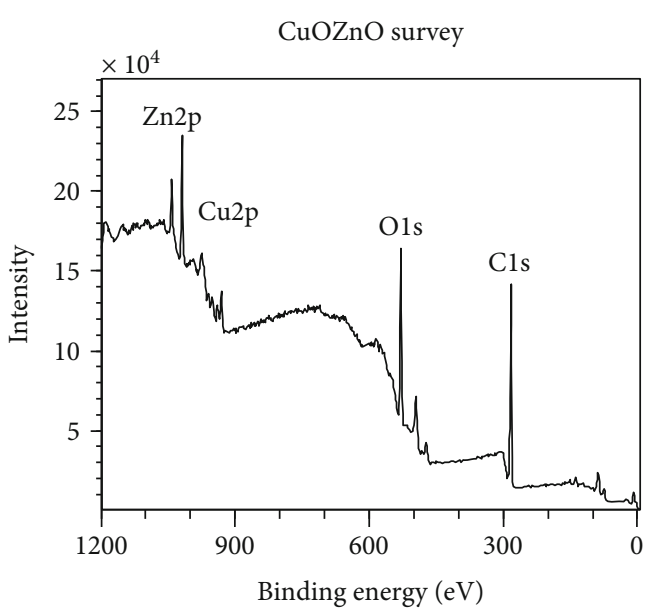

(a)



(b)

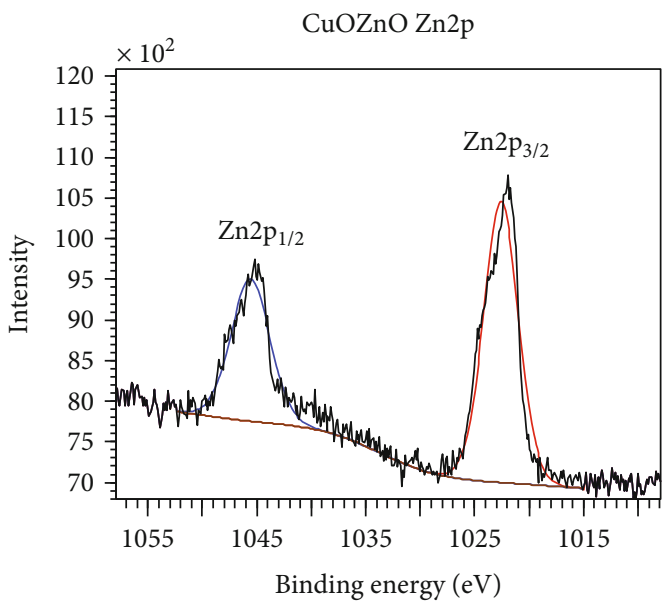

(c)

Figure 6: XPS spectra of $\mathrm{ZnO} / \mathrm{CuO}$ (a) survey spectrum, (b) $\mathrm{Cu} 2 \mathrm{p}$ where Sat denoted as satellite peaks, and (c) Zn2p1/2 spectrum.

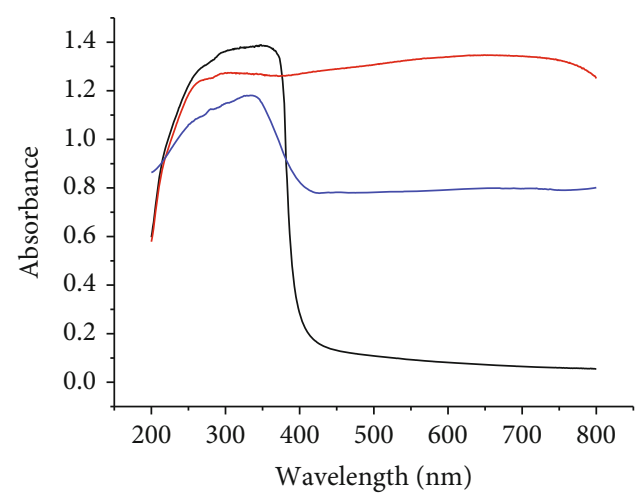

(a)



(b)

Figure 7: (a) UV-Vis diffuse reflectance spectra and (b) Tauc's plots of $\mathrm{ZnO}, \mathrm{CuO}$, and $\mathrm{ZnO} / \mathrm{CuO}$.

the result of the collapse of the porous structure after calcination, leading to the disappearance of the adsorption sites. As can be seen from Figure 9(b), $\mathrm{CuO}$ could not catalyze any $\mathrm{MB}$ degradation, while $\mathrm{ZnO}$ and $\mathrm{ZnO} / \mathrm{CuO}$ exhibit photocatalytic activities in both visible and ultraviolet regions. It is worth noting that $\mathrm{ZnO} / \mathrm{CuO}$ demonstrates an excellent 


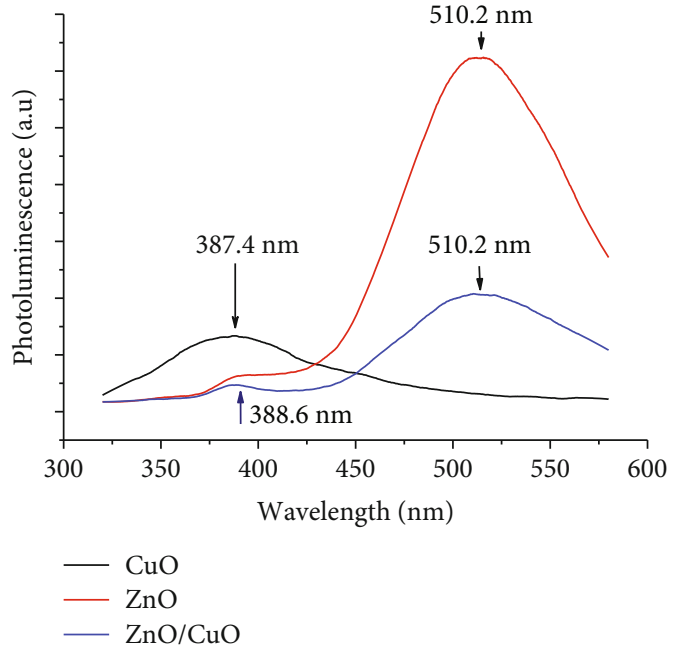

Figure 8: Photoluminescence spectra of $\mathrm{CuO}, \mathrm{ZnO}$, and $\mathrm{ZnO} / \mathrm{CuO}$.

photocatalytic activity, and the complete decolorization of MB occurs after 120 min under visible illumination. Meanwhile, $\mathrm{ZnO}$ (UV) and $\mathrm{ZnO}$ (Vis) decolorize $\mathrm{MB}$ up to 95 and $90 \%$, respectively, after $240 \mathrm{~min}$ of illumination. The $\mathrm{ZnO} / \mathrm{CuO}$ composite also catalyzes $\mathrm{MB}$ degradation faster than pure $\mathrm{CuO}$ or $\mathrm{ZnO}$ under visible light illumination. In fact, after 120 minutes, its decolorization efficiency is 1.57 and 7.7 times as high as that of $\mathrm{ZnO}$ and $\mathrm{CuO}$, respectively. The porous $\mathrm{ZnO} / \mathrm{CuO}$ composite with a large surface area would provide the heterojunction structure and an effective environment for a larger number of surface active sites. This increases $\mathrm{MB}-\mathrm{ZnO} / \mathrm{CuO}$ interaction and thus promoting photodegradation. In other words, the combination of $\mathrm{ZnO}$ and $\mathrm{CuO}$ causes the synergistic effect in the catalytic degradation of methylene blue.

3.2.2. Effect of $\mathrm{pH}$ and Leaching Experiment. Effect of $\mathrm{pH}$ on decolorization of $\mathrm{MB}$ over $\mathrm{ZnO} / \mathrm{CuO}$ catalyst is shown in Figure 10(a). The decolorization performance seems to be unchangeable in $\mathrm{pH}$ range from 2 to 7 and increases significantly when $\mathrm{pH}$ increases. The point of zero charge $\left(\mathrm{pH}_{\mathrm{pzc}}\right)$ for $\mathrm{ZnO} / \mathrm{CuO}$, determined using the $\mathrm{pH}$ drift method, is around 7.9 (Figure 10(b)) [47]. At lower pH (lower than $\mathrm{pH}_{\mathrm{pzc}}$ ), the surface of $\mathrm{ZnO} / \mathrm{CuO}$ is positively charged. When $\mathrm{pH}$ increases from 2 to 7 , the surface becomes less positive and the decolorization efficiency increases slightly. At higher $\mathrm{pH}$ (higher than $\mathrm{pH}_{\mathrm{pzc}}$ ), the surface of $\mathrm{ZnO} / \mathrm{CuO}$ is negatively charged; hence, $\mathrm{MB}$ and the catalyst attract each other through electrostatic interaction; thus, the decolorization efficiency increases significantly.

During the leaching experiment, the catalyst was filtered after 30 min and the decolorization of MB under illumination almost stops (Figure 10(c)). In addition, the decolorization of $\mathrm{MB}$ without the catalyst is not observed after $70 \mathrm{~min}$ of illumination, indicating that $\mathrm{MB}$ is stable in the visible light region. Therefore, it can be inferred that $\mathrm{ZnO} / \mathrm{CuO}$ acts as a heterogeneous catalyst in the photocatalytic degradation of methylene blue.
3.2.3. Visible-Light-Driven Photocatalytic Degradation of $M B$ with $\mathrm{ZnO} / \mathrm{CuO}$ Composite. The absorption bands at $292 \mathrm{~nm}$ and at $664 \mathrm{~nm}$ on the UV-Vis absorption spectra of $\mathrm{MB}$ can be attributed to the benzene ring and the conjunction color group $-\mathrm{N}=\mathrm{N}-$, respectively (Figure 11(a)). The intensity of these bands decreases with the increasing illumination time, and they almost disappear after 90 min of the reaction. The decolorization of $\mathrm{MB}$ occurs due to the disappearance of the color conjunction group during illumination. The TOC test also proves the mineralization of $\mathrm{MB}$ during photocatalytic degradation (Figure 11(b)). The TOC of MB reduces significantly from $6.35 \mathrm{mg} \cdot \mathrm{L}^{-1}$ for initial solution to $0.72 \mathrm{mg} \cdot \mathrm{L}^{-1}$ after $140 \mathrm{~min}$ of illumination, indicating complete mineralization of $\mathrm{MB}$ over $\mathrm{ZnO} / \mathrm{CuO}$ composite.

In order to clarify the radical mechanism of the degradation reaction, three radical scavengers (KI for electron holes, isopropanol for $\mathrm{OH}$, and benzoquinone for $\mathrm{O}^{2 \cdot-}$ ) were used in the present experiment. It is evident that the addition of isopropanol causes a moderate reduction in photocatalytic activity, while KI practically impedes the photocatalytic degradation of MB (Figure 12). Benzoquinone hinders degradation by around $50 \%$. This infers that electron holes and superoxides play an important role in $\mathrm{MB}$ degradation.

A mechanism of photocatalysis on a semiconductor is employed to explain the photocatalytic activities in the visible light region. Since the band gap positions for the conduction band of $\mathrm{CuO}$ and $\mathrm{ZnO}$ are $-0.43 \mathrm{eV}$ and $-0.15 \mathrm{eV}$ vs. NHE, respectively $[9,48]$, and the band gaps of $\mathrm{CuO}$ and $\mathrm{ZnO}$ are 1.94 and $3.19 \mathrm{eV}$, then the band gap positions for valence bands are $1.51 \mathrm{eV}$ for $\mathrm{CuO}$ and $3.04 \mathrm{eV}$ for $\mathrm{ZnO}$ (see Table S3). Due to the strong light adsorption capacity of $\mathrm{CuO}$ in the visible light region, electrons are excited from $\mathrm{VB}$ to $\mathrm{CB}$ to form photogenerated $\mathrm{h}^{+} / \mathrm{e}^{-}$pairs. The position of $\mathrm{CB}$ in $\mathrm{CuO}$ is more negative than that in $\mathrm{ZnO}$; hence, the transfer of the excited electrons to $E_{\mathrm{CB}}(\mathrm{ZnO})$ prevents the fast recombination of photoexcited $\mathrm{e}^{-} / \mathrm{h}^{+}$pairs (equations (9) and (10)). On the other hand, the state of $\mathrm{MB}(1.17 \mathrm{eV})$ could be excited to $\mathrm{MB}^{*}(-0.69 \mathrm{eV})$ by visible light $[49,50]$ (equation (11)). The work function of the photoexcited $\mathrm{MB}^{*}(-0.69 \mathrm{eV})$ is more negative than that of $\mathrm{CuO}$ and $\mathrm{ZnO}[49,50]$. $\mathrm{MB}$ acts as the photosensitizer to provide additional photogenerated electrons into $\mathrm{CBs}$ of $\mathrm{CuO}$ and $\mathrm{ZnO}$ through the formed downstream channel (equations (12) and (13)). The VB potential for $\mathrm{CuO}(1.51 \mathrm{eV})$ is more positive than that of $\mathrm{MB}(1.17 \mathrm{eV})$; therefore, $\mathrm{h}^{+}$could easily oxidize $\mathrm{MB}$ to form degradation products (equation (14)). On the other hand, the $\mathrm{CB}$ edge position of $\mathrm{CuO}$ $(-0.43 \mathrm{eV})$ is more negative than that of $E^{0}\left(\mathrm{O}_{2} / \mathrm{O}_{2}{ }^{-}\right)$ $(-0.33 \mathrm{eV})[51]$; thus, electrons on the conduction band of $\mathrm{CuO}$ reacts with $\mathrm{O}_{2}$ to produce superoxide radical $\mathrm{O}_{2}$, which could substantially oxidize $\mathrm{MB}$ to form degradation products (equations (15) and (16)). In principle, $\mathrm{h}^{+}$ $(1.51 \mathrm{eV})$ could not oxidize $\mathrm{H}_{2} \mathrm{O}\left(E\left(\mathrm{H}_{2} \mathrm{O} / \mathrm{OH}\right)=2.6 \mathrm{eV}\right)$, but the experimental result still indicates the role of ${ }^{\circ} \mathrm{OH}$ in the oxygenation of dye as shown in Figure 12. This is still a challenging problem possibly due to the deviation between theoretical and practical estimation. The transfer path of 


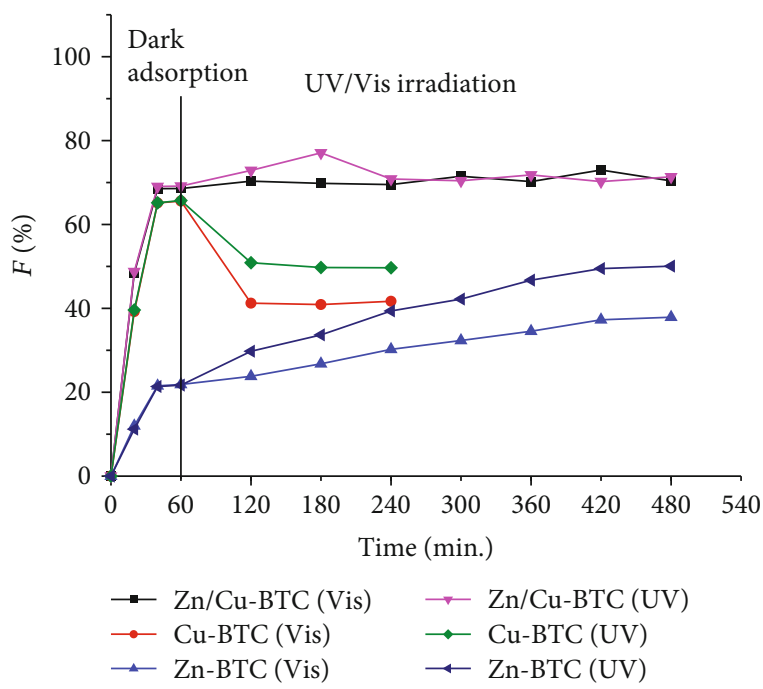

(a)

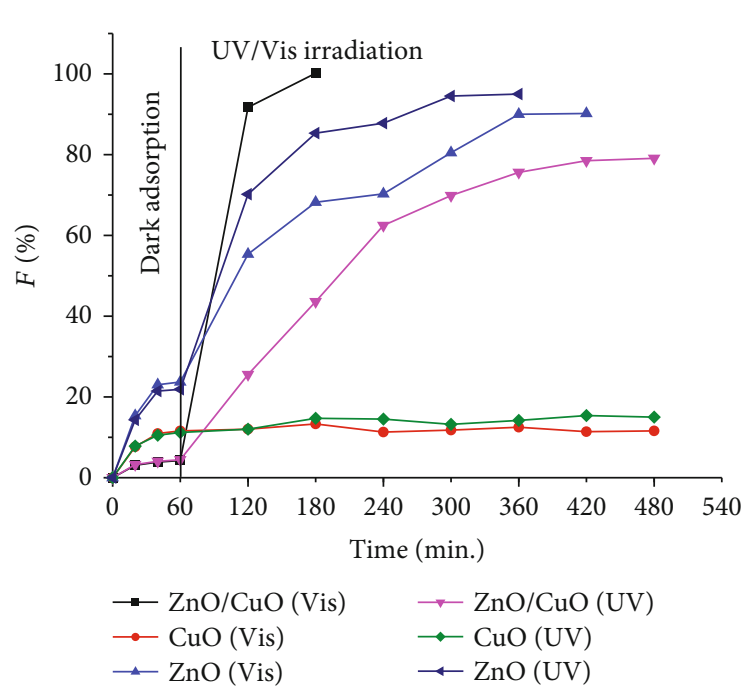

(b)

Figure 9: Decolorization of MB over (a) as-prepared $\mathrm{Zn}-\mathrm{BTC}$, $\mathrm{Cu}-\mathrm{BTC}, \mathrm{Zn} / \mathrm{Cu}-\mathrm{BTC}$, and (b) $\mathrm{CuO}, \mathrm{ZnO}$, and $\mathrm{ZnO} / \mathrm{CuO}$ under UV and visible irradiation (conditions: $V=500 \mathrm{~mL} ; m_{\text {catalyst }}=400 \mathrm{mg}$; concentration of $\mathrm{MB}=10 \mathrm{ppm}$ ).

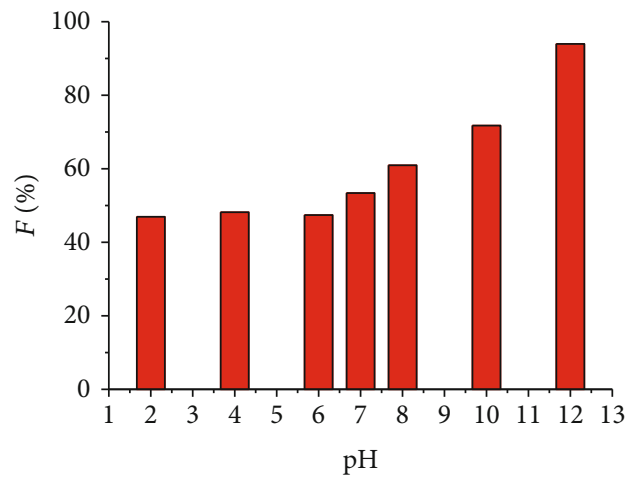

(a)

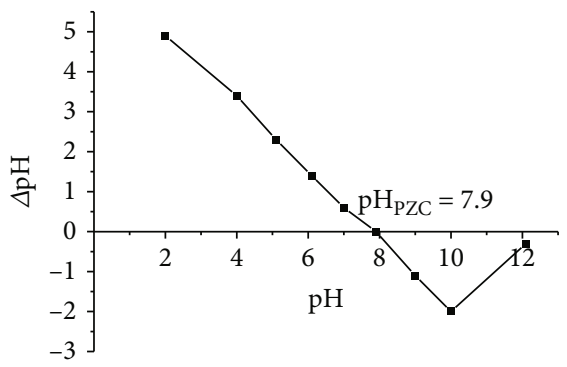

(b)

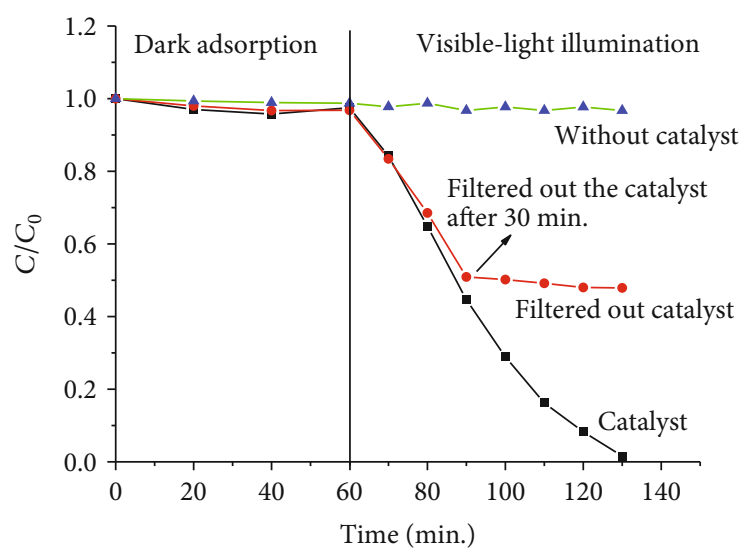

(c)

FIGURE 10: (a) Effect of $\mathrm{pH}$ on decolorization of $\mathrm{MB}$ over porous $\mathrm{ZnO} / \mathrm{CuO}$ octahedron catalyst; (b) the point of zero charge obtained from the $\mathrm{pH}$ drift $\operatorname{method}\left(V=100 \mathrm{~mL}, C_{0}=10 \mathrm{mg} \cdot \mathrm{L}^{-1} ; m_{\text {catalyst }}=80 \mathrm{mg}\right.$; adsorption time $=60 \mathrm{~min}$; illumination time $\left.=70 \mathrm{~min}\right) ;(\mathrm{c})$ leaching experiment $\left(V=500 \mathrm{~mL} ; C_{0}=10 \mathrm{mg} \cdot \mathrm{L}^{-1} ; m_{\text {catalyst }}=400 \mathrm{mg}\right.$, adsorption time $\left.=60 \mathrm{~min}\right)$. 


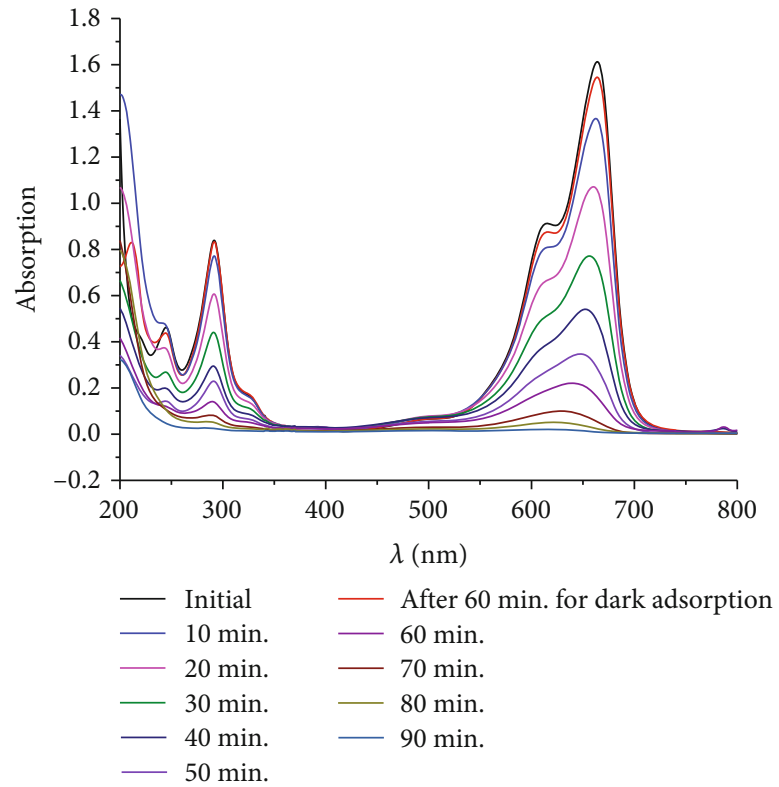

(a)

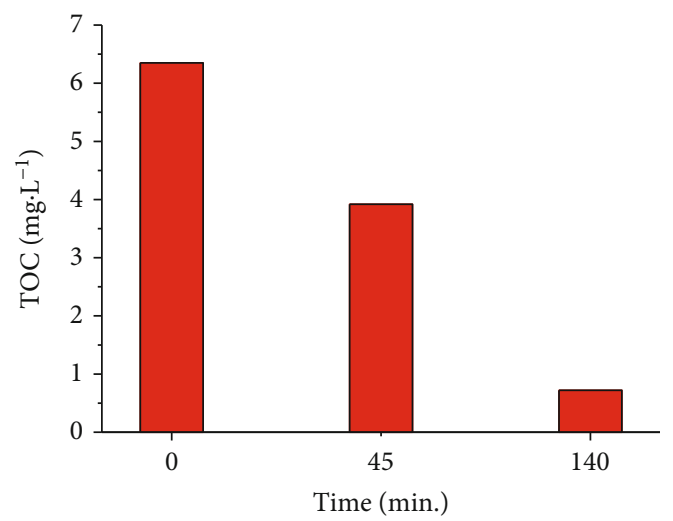

(b)

FIgURE 11: (a) UV-Vis absorption spectra at different times and (b) TOC of MB solution in the photocatalytic degradation ( $V=500 \mathrm{~mL}$; $C_{0}=10 \mathrm{ppm} ; m_{\text {catalyst }}=400 \mathrm{mg}$; adsorption time $\left.=60 \mathrm{~min}\right)$.

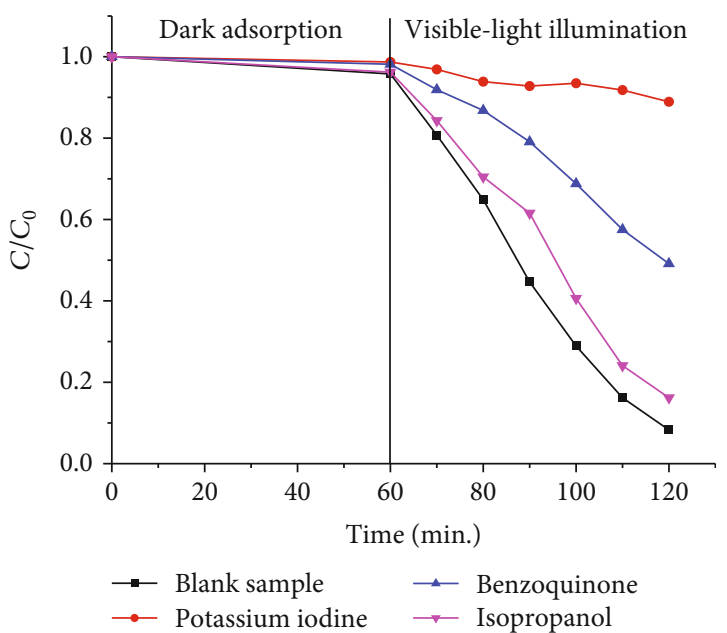

FIgURE 12: Effect of radical scavengers (potassium iodide, isopropanol, and benzoquinone) on $\mathrm{MB}$ decolorization over porous $\mathrm{ZnO} / \mathrm{CuO}$ octahedrons catalyst $\left(V=100 \mathrm{~mL} ; C_{0}=10 \mathrm{ppm}\right.$; $m_{\text {catalyst }}=80 \mathrm{mg}$; adsorption time $=60 \mathrm{~min}$; concentration of scavenger solution: $2.4 \times 10^{-4} \mathrm{M}$ ).

photogenerated charge carriers under visible light illumination is illustrated in Figure 13.

$$
\begin{aligned}
\mathrm{ZnO} / \mathrm{CuO}+h v & \longrightarrow \mathrm{ZnO} / \mathrm{CuO}\left(\mathrm{h}^{+}+\mathrm{e}^{-}\right) \\
\mathrm{ZnO} / \mathrm{CuO}\left(\mathrm{e}^{-} / \mathrm{CB}\right) & \longrightarrow\left(\mathrm{e}^{-} / \mathrm{CB}\right) \mathrm{ZnO} / \mathrm{CuO} \\
\mathrm{MB}+h v & \longrightarrow \mathrm{MB}^{*} \\
\mathrm{MB}^{*} & \longrightarrow \mathrm{e}^{-}+\mathrm{MB}^{*+}
\end{aligned}
$$

$$
\begin{aligned}
\mathrm{MB}^{*+} & \longrightarrow \mathrm{MB}+\mathrm{h}^{+} \\
\mathrm{CuO}\left(\mathrm{h}^{+}\right)+\mathrm{MB} & \longrightarrow \text { degradation products } \\
\mathrm{CuO}\left(\mathrm{e}^{-} / \mathrm{CB}\right)+\mathrm{O}_{2} & \longrightarrow \mathrm{O}_{2}{ }^{--}+\mathrm{ZnO} \\
\mathrm{O}_{2}{ }^{--}+\mathrm{MB} & \longrightarrow \text { degradation products }
\end{aligned}
$$

3.2.4. Kinetics of MB Photocatalytic Degradation. The kinetics of adsorption and photocatalytic degradation is presented in Figure 14(a). It is evident that the adsorption reaches equilibrium after $60 \mathrm{~min}$ in the dark $(\mathrm{MB}$ concentrations of $5 \sim 30 \mathrm{ppm})$. The values of the maximum monolayer adsorption capacity $\left(q_{\mathrm{m}}\right)$ and the Langmuir equilibrium constant (obtained from the nonlinear plot of $q_{\mathrm{e}}$ vs. $C_{\mathrm{e}}$ (equation (5))) are $1.63 \mathrm{mg} \cdot \mathrm{g}^{-1}$ and $0.047 \mathrm{~L} \cdot \mathrm{mg}^{-1}$, respectively (Figure S3 and Table S4). Equation (8) becomes

$$
\frac{1}{0.047} \cdot \ln C+C=-k_{\mathrm{r}} \cdot t+\frac{1}{0.047} \cdot \ln C_{\mathrm{e}}+C_{\mathrm{e}} .
$$

The values of $k_{\mathrm{r}}$ can be calculated from the slope of equation (17) $(((1 / 0.047) \times \ln C+C)$ vs. $t$, Figure $14(\mathrm{~b})$ and Table 2). The classical kinetic model (pseudo-first-orderkinetic model) in the linear form as equation (1) is employed to analyze the kinetic data for comparing the goodness of fit (Table 2). The paired sample $t$ test with $\alpha=0.05$ shows that the proposed model provides statistically higher determination coefficients than the pseudo-firstorder kinetic model $(t(4)=5.899$, $p$ value $=0.002(<0.05))$, indicating that the proposed model fits the data more accurately than the classical kinetic model.

It is difficult to compare the catalytic activity of $\mathrm{ZnO} / \mathrm{CuO}$ composite in the present with that of other catalysts 


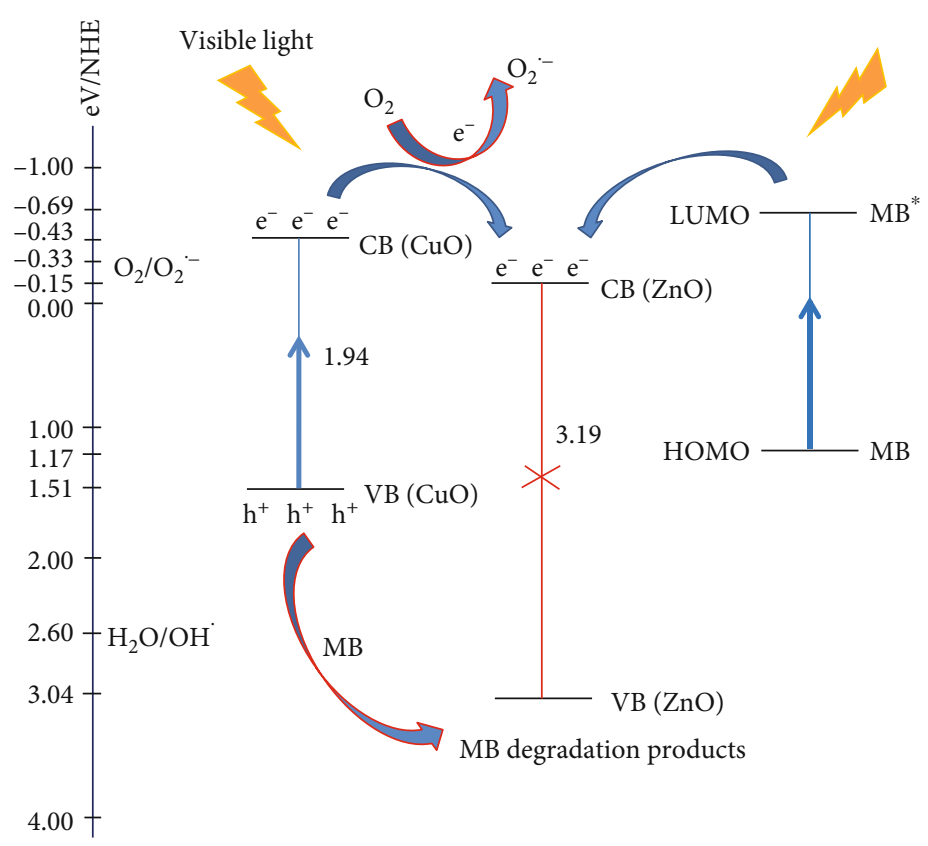

FIGURE 13: Energy of valence band edge and conduction band edge for $\mathrm{ZnO} / \mathrm{CuO}$ coupling semiconductor (HOMO: highest occupied molecular orbital and LUMO: lowest unoccupied molecular orbital).

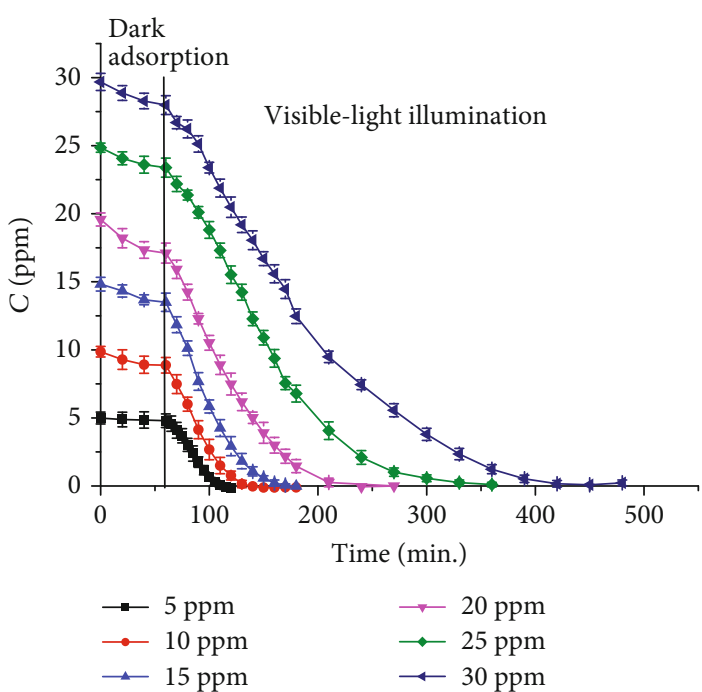

(a)

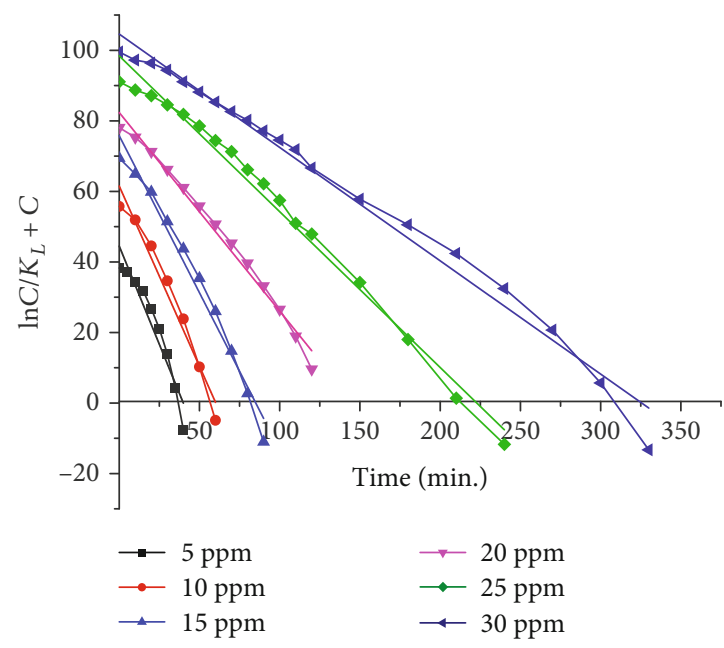

(b)

FIGURE 14: (a) Kinetics of adsorption and photocatalytic degradation of methylene blue over octahedral $\mathrm{ZnO} / \mathrm{CuO}$ catalyst; (b) linear plots of the proposed kinetic model (conditions: $V=500 \mathrm{~mL}, C_{0}=5-30 \mathrm{mg} \cdot \mathrm{L}^{-1}, m_{\text {catalyst }}=400 \mathrm{mg}$, temperature $=35^{\circ} \mathrm{C}$ ).

previously reported due to different light sources (UV or Vis), the initial concentration of reactants, the amount of catalyst, the reaction volume, etc. The pseudo-first-rate constant appears to be relevant because several authors report the catalytic activity in terms of this value (Table 3 ). The value of the pseudo-first-rate constant for the degradation on the present catalyst in the visible region is lower than that for graphene-like carbon/ $\mathrm{TiO}_{2}$ and $\mathrm{ZnO} /$ graphene oxide in the UV region and compatible with commercial P25, but higher than that for other catalysts reported such as $\mathrm{Ta}-\mathrm{ZnO}$, $\mathrm{g}^{-} \mathrm{C}_{3} \mathrm{~N}_{4} / \mathrm{CdS}$, and $\mathrm{Ce}-\mathrm{TiO}_{2}$.
3.2.5. Recyclability. Recyclability is an important factor in heterogeneous catalysis. After the cycling experiment, the $\mathrm{ZnO} / \mathrm{CuO}$ catalyst was first separated by centrifugation, then washed with water and ethanol for three times to remove the dye, and finally dried at $120^{\circ} \mathrm{C}$ for $15 \mathrm{~h}$. The photocatalytic degradation efficiency of $\mathrm{ZnO} / \mathrm{CuO}$ decreases from $100 \%$ to $97.2 \%$ after three cycles (Figure 15(a)). The $\mathrm{XRD}$ patterns of the recycled $\mathrm{ZnO} / \mathrm{CuO}$ samples stay unaltered; therefore, it can be inferred that $\mathrm{ZnO} / \mathrm{CuO}$ remains stable during photocatalytic degradation reactions (Figure 15(b)). 
TABLE 2: Determination coefficients of the proposed model in the linear form and apparent rate coefficients.

\begin{tabular}{lcccc}
\hline $\begin{array}{l}\text { Initial MB concentration } \\
C_{0}\left(\mathrm{mg} \cdot \mathrm{L}^{-1}\right)\end{array}$ & $R^{2}$ (proposed model) & $\begin{array}{c}\text { Apparent rate coefficient, } \\
k_{\mathrm{r}}\left(\mathrm{mg} \cdot \mathrm{L}^{-1} \cdot \mathrm{min}^{-1}\right)\end{array}$ & $\begin{array}{c}R^{2} \text { (pseudo-first-order } \\
\text { kinetic model) }\end{array}$ & $\begin{array}{c}\text { Pseudo-rate } \\
\text { constant } k\left(\mathrm{~min}^{-1}\right)\end{array}$ \\
\hline 5 & 0.919 & 1.1138 & 0.8303 & 0.0721 \\
10 & 0.968 & 1.0219 & 0.8832 & 0.0532 \\
15 & 0.978 & 0.8909 & 0.9146 & 0.0447 \\
20 & 0.988 & 0.5629 & 0.8816 & 0.0367 \\
25 & 0.988 & 0.4417 & 0.9630 & 0.0179 \\
30 & 0.986 & 0.3213 & 0.9330 & 0.0132 \\
\hline
\end{tabular}

TABLE 3: Comparison of the pseudo-first-order rate constant of the present catalyst with that of other catalysts.

\begin{tabular}{|c|c|c|c|c|c|}
\hline Catalyst & $\mathrm{S}_{\mathrm{BET}}\left(\mathrm{m}^{2} \cdot \mathrm{g}^{-1}\right)$ & $\begin{array}{l}\text { Light source } \\
\text { (nm, power) }\end{array}$ & $\begin{array}{c}C_{0}\left(\mathrm{mg} \cdot \mathrm{L}^{-1}\right) / \text { volume }(\mathrm{mL}) / \\
m_{\text {catalyst }}(\mathrm{mg})\end{array}$ & $\begin{array}{l}\text { Pseudo-first-order rate } \\
\text { constant, } k\left(\mathrm{~min}^{-1}\right)\end{array}$ & References \\
\hline $\mathrm{ZnO}$ & 8.21 & $\mathrm{UV}, 20 \mathrm{~W}$ & $10 / 100 / 50$ & 0.022 & {$[52]$} \\
\hline $\mathrm{ZnO/graphene} \mathrm{oxide}$ & 31.58 & $\mathrm{UV}, 20 \mathrm{~W}$ & $10 / 100 / 50$ & 0.098 & {$[52]$} \\
\hline Pristine $\mathrm{TiO}_{2}(\mathrm{P} 25)$ & - & $254,11 \mathrm{~W}$ & $10 / 100 / 50$ & 0.009 & {$[53]$} \\
\hline Graphene-like carbon/ $\mathrm{TiO}_{2}$ & - & $254,11 \mathrm{~W}$ & $10 / 100 / 50$ & 0.248 & {$[53]$} \\
\hline Pristine $\mathrm{TiO}_{2}(\mathrm{P} 25)$ & 51 & $\leq 370,18 \mathrm{~W}$ & $9.6 / 100 / 50$ & 0.043 & {$[54]$} \\
\hline $\mathrm{Sm}-\mathrm{TiO}_{2}$ & 46 & $370,18 \mathrm{~W}$ & $9.60 / 100 / 50$ & 0.020 & {$[54]$} \\
\hline $\mathrm{Ce}-\mathrm{TiO}_{2}$ & 46 & $370,18 \mathrm{~W}$ & $9.60 / 100 / 50$ & 0.024 & {$[54]$} \\
\hline $\mathrm{TiO}_{2}$ & 50 & $340,125 \mathrm{~W}$ & $23 / 2750 / 375$ & 0.025 & [55] \\
\hline CdS & 111.2 & $>420,500 \mathrm{~W}$ & $25 / 200 / 80$ & 0.0079 & {$[56]$} \\
\hline $\mathrm{g}-\mathrm{C}_{3} \mathrm{~N}_{4}$ & 9.8 & $>420,500 \mathrm{~W}$ & $25 / 200 / 80$ & 0.0039 & {$[56]$} \\
\hline $\mathrm{g}-\mathrm{C}_{3} \mathrm{~N}_{4}$-CdS & 166.5 & $>420,500 \mathrm{~W}$ & $25 / 200 / 80$ & 0.0121 & {$[56]$} \\
\hline $\mathrm{Ag} / \mathrm{ZnO}$ & - & $\begin{array}{l}>570 \text { (high pressure } \\
\text { sodium lamp) }\end{array}$ & $5 /-/ 150$ & 0.006 & [57] \\
\hline $\mathrm{Ta}-\mathrm{ZnO}$ & 36 & $>420,300$ & $10 / 50 / 50$ & 0.0401 & {$[58]$} \\
\hline $\mathrm{CeO}_{2}-\mathrm{TiO}_{2}$ & 66 & $>420,160$ & $10 / 100 / 80$ & 0.0341 & [59] \\
\hline $\mathrm{ZnO} / \mathrm{CuO}$ & 33 & $>420,160$ & $10 / 500 / 400$ & 0.0532 & This work \\
\hline
\end{tabular}

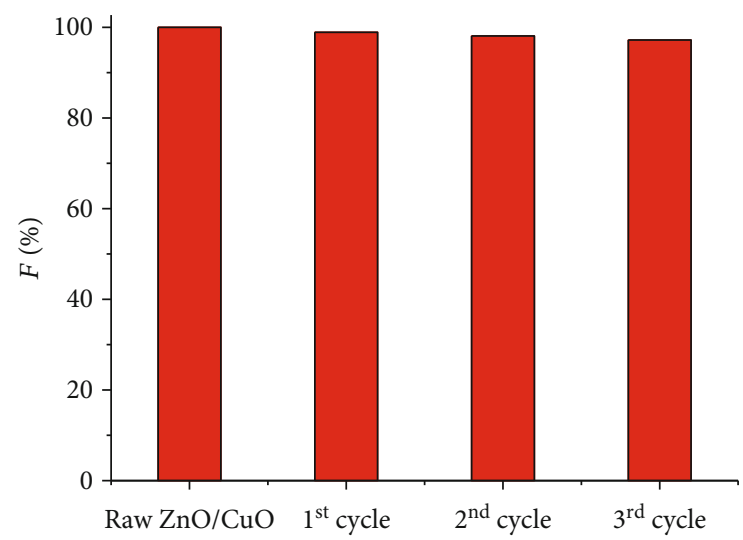

(a)

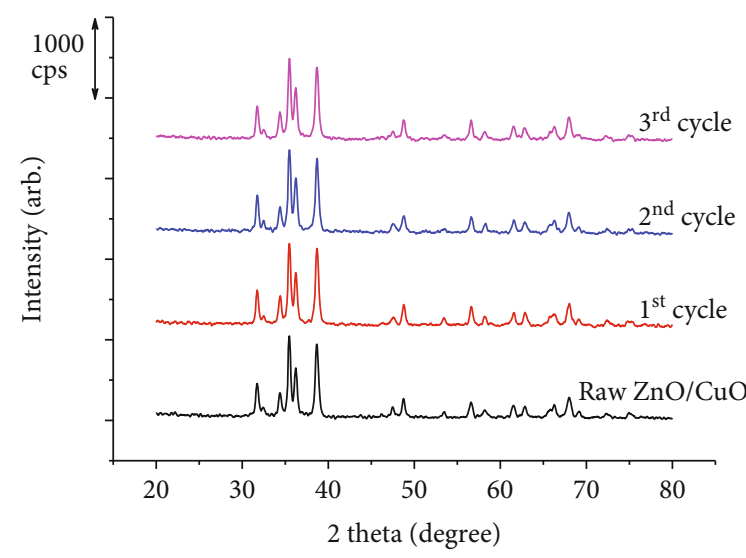

(b)

Figure 15: (a) Photocatalytic degradation efficiency of used catalysts; (b) XRD patterns of $\mathrm{ZnO} / \mathrm{CuO}$ after the third cycle ( $V=1000 \mathrm{~mL}$, $C_{0}=10 \mathrm{ppm}, m_{\text {catalyst }}=800 \mathrm{mg}$; adsorption time $=60 \mathrm{~min}$; light illumination time $\left.=80 \mathrm{~min}\right)$.

In addition, the obtained catalyst manifests excellent photocatalytic degradation of several other dyes, including phenol, phenol red, methyl orange, and Congo red (Figure 16).
Porous octahedral $\mathrm{ZnO} / \mathrm{CuO}$ composite exhibits superior visible-light-driven photocatalytic degradation of $\mathrm{MB}$ compared with single $\mathrm{CuO}$ or $\mathrm{ZnO}$. 




FIgURE 16: Visible-light driven photocatalytic degradation of several dyes over $\mathrm{ZnO}, \mathrm{CuO}$, and porous octahedral $\mathrm{ZnO} / \mathrm{CuO}$ composite (condition: concentration of dyes $=10 \mathrm{ppm} ; V=500 \mathrm{~mL} ; m_{\text {catalyst }}=$ $400 \mathrm{mg}$; illumination time $=540 \mathrm{~min}$ ).

\section{Conclusions}

In this study, a porous octahedral $\mathrm{ZnO} / \mathrm{CuO}$ composite was synthesized from $\mathrm{Zn} / \mathrm{Cu}$-based MOF-199. The fabricated $\mathrm{ZnO} / \mathrm{CuO}$ composite possesses a hierarchical 3D structure consisted of porous octahedral particles of $5-10 \mu \mathrm{m}$ in size. Compared with pure $\mathrm{ZnO}$ and $\mathrm{CuO}$, the as-prepared $\mathrm{ZnO}$ / $\mathrm{CuO}$ composite exhibits superior photocatalytic degradation of phenol and different dyes (methyl blue, methyl orange, phenol red, and Congo red) in the visible light region. The formation of a stable $p-n$ junction that efficiently separates the photogenerated electron-hole pairs within each semiconductor material is responsible for the degradation. The synthesized photocatalyst remains stable after four cycles of application. The kinetic model of photocatalytic degradation with a unimolecular reaction over heterogeneous catalyst combined with the Langmuir adsorption isotherm is proposed. This model is statistically consistent with the experimental data. The porous $\mathrm{ZnO} / \mathrm{CuO}$ octahedron composite is an active and stable visible-light-driven catalyst and may serve as a potential catalyst for practical use in the treatment of dye pollutants in aquatic effluents.

\section{Data Availability}

The data used to support the findings of this study are available from the corresponding author upon request.

\section{Conflicts of Interest}

The authors declare that they have no conflicts of interest.

\section{Acknowledgments}

This research was sponsored by Hue University under Decision No. 1208/QĐ-DHH.

\section{Supplementary Materials}

Table S1 presents the weight loss and temperature range derived from TG-DTA measurement of Cu-BTC, Zn-BTC, and $\mathrm{Zn} / \mathrm{Cu}-\mathrm{BTC}$. The specific surface areas calculated by using the BET model, porous diameters, and volumes for the resulting materials were obtained from the analysis of nitrogen adsorption isotherm data (Table S2). Band gap energy and band edge position of $\mathrm{CuO}, \mathrm{ZnO}$, and $\mathrm{ZnO} /$ $\mathrm{CuO}$ calculated by using Tauc's equation are listed in Table S3. The parameters of the Langmuir and Freudlich isotherm models in linear forms are listed in Table S4 and illustrated in Figure S3. CuO prepared by the pyrolysis of $\mathrm{Cu}-\mathrm{BTC}$ at $400^{\circ} \mathrm{C}$ for $5 \mathrm{~h}$ retained the octahedral particles as intimal $\mathrm{Cu}-\mathrm{BTC}$ (Figure S1). The EDX measurement revealed that zinc and copper coexisted in $\mathrm{ZnO} / \mathrm{CuO}$ sample. (Supplementary Materials)

\section{References}

[1] A. Janotti and C. G. Van de Walle, "Fundamentals of zinc oxide as a semiconductor," Reports on Progress in Physics, vol. 72, no. 12, article 126501, 2009.

[2] D. C. Reynolds, D. C. Look, and B. Jogai, "Optically pumped ultraviolet lasing from ZnO," Solid State Communications, vol. 99, no. 12, pp. 873-875, 1996.

[3] Z.-L. Liu, J.-C. Deng, J.-J. Deng, and F.-F. Li, "Fabrication and photocatalysis of $\mathrm{CuO} / \mathrm{ZnO}$ nano-composites via a new method," Materials Science and Engineering: B, vol. 150, no. 2, pp. 99-104, 2008.

[4] C. $\mathrm{Xu}, \mathrm{L}$. Cao, G. Su et al., "Preparation of $\mathrm{ZnO} / \mathrm{Cu}_{2} \mathrm{O}$ compound photocatalyst and application in treating organic dyes," Journal of Hazardous Materials, vol. 176, no. 1-3, pp. 807-813, 2010.

[5] P. Li, Z. Wei, T. Wu, Q. Peng, and Y. Li, "Au-ZnO hybrid nanopyramids and their photocatalytic properties," Journal of the American Chemical Society, vol. 133, no. 15, pp. 56605663, 2011.

[6] W. Wu, S. Zhang, X. Xiao et al., "Controllable synthesis, magnetic properties, and enhanced photocatalytic activity of spindlelike mesoporous $\alpha-\mathrm{Fe}_{2} \mathrm{O}_{3} / \mathrm{ZnO}$ core-shell heterostructures," ACS Applied Materials \& Interfaces, vol. 4, no. 7, pp. 3602-3609, 2012.

[7] R. Saravanan, S. Karthikeyan, V. Gupta, G. Sekaran, V. Narayanan, and A. Stephen, "Enhanced photocatalytic activity of $\mathrm{ZnO} / \mathrm{CuO}$ nanocomposite for the degradation of textile dye on visible light illumination," Materials Science and Engineering: C, vol. 33, no. 1, pp. 91-98, 2013.

[8] B. Li and Y. Wang, "Facile synthesis and photocatalytic activity of $\mathrm{ZnO}-\mathrm{CuO}$ nanocomposite," Superlattices and Microstructures, vol. 47, no. 5, pp. 615-623, 2010.

[9] A. Kargar, Y. Jing, S. J. Kim, C. T. Riley, X. Pan, and D. Wang, " $\mathrm{ZnO} / \mathrm{CuO}$ heterojunction branched nanowires for photoelectrochemical hydrogen generation," ACS Nano, vol. 7, no. 12, pp. 11112-11120, 2013. 
[10] Y. Zhang, S. Yuan, G. Day, X. Wang, X. Yang, and H.-C. Zhou, "Luminescent sensors based on metal-organic frameworks," Coordination Chemistry Reviews, vol. 354, pp. 28-45, 2018.

[11] H.-C. J. Zhou and S. Kitagawa, Eds., "Metal-organic frameworks (MOFs)," Chemical Society Reviews, vol. 43, no. 16, pp. 5415-5418, 2014.

[12] K. K. Gangu, S. Maddila, S. B. Mukkamala, and S. B. Jonnalagadda, "A review on contemporary metal-organic framework materials," Inorganica Chimica Acta, vol. 446, pp. 61-74, 2016.

[13] S. S.-Y. Chui, S. M.-F. Lo, J. P. H. Charmant, A. G. Orpen, and I. D. Williams, "A chemically functionalizable nanoporous material $\left[\mathrm{Cu}_{3}(\mathrm{TMA})_{2}\left(\mathrm{H}_{2} \mathrm{O}\right)_{3}\right]$ n," Science, vol. 283, no. 5405, pp. 1148-1150, 1999.

[14] S. L. Ho, I. C. Yoon, C. S. Cho, and H.-J. Choi, "A recyclable metal-organic framework MOF-199 catalyst in coupling and cyclization of $\beta$-bromo- $\alpha, \beta$-unsaturated carboxylic acids with terminal alkynes leading to alkylidenefuranones," Journal of Organometallic Chemistry, vol. 791, pp. 13-17, 2015.

[15] Y. Jiang, X. Zhang, X. Dai et al., "Microwave-assisted synthesis of ultrafine Au nanoparticles immobilized on MOF-199 in high loading as efficient catalysts for a three-component coupling reaction," Nano Research, vol. 10, no. 3, pp. 876-889, 2017.

[16] E. Ghorbani-Kalhor, "A metal-organic framework nanocomposite made from functionalized magnetite nanoparticles and HKUST-1 (MOF-199) for preconcentration of Cd(II), $\mathrm{Pb}(\mathrm{II})$, and Ni(II)," Microchimica Acta, vol. 183, no. 9, pp. 26392647, 2016.

[17] M. Anbia, M. Faryadras, and A. Ghaffarinejad, "Synthesis and characterization of $\mathrm{Zn}_{3}(\mathrm{BTC})_{2}$ nanoporous sorbent and its application for hydrogen storage at ambient temperature," Journal of Applied Chemical Research, vol. 9, no. 3, pp. 3341,2015

[18] A. A. Tehrani, V. Safarifard, A. Morsali, G. Bruno, and H. A. Rudbari, "Ultrasound-assisted synthesis of metal-organic framework nanorods of Zn-HKUST-1 and their templating effects for facile fabrication of zinc oxide nanorods via solidstate transformation," Inorganic Chemistry Communications, vol. 59, pp. 41-45, 2015.

[19] L. Xu, E.-Y. Choi, and Y.-U. Kwon, "Ionothermal synthesis of a 3D Zn-BTC metal-organic framework with distorted tetranuclear $\left[\mathrm{Zn}_{4}\left(\mu_{4}-\mathrm{O}\right)\right]$ subunits," Inorganic Chemistry Communications, vol. 11, no. 10, pp. 1190-1193, 2008.

[20] J. I. Feldblyum, M. Liu, D. W. Gidley, and A. J. Matzger, "Reconciling the discrepancies between crystallographic porosity and guest access as exemplified by Zn-HKUST-1," Journal of the American Chemical Society, vol. 133, no. 45, pp. 18257-18263, 2011.

[21] C. T. Pereira da Silva, B. N. Safadi, M. P. Moisés et al., "Synthesis of Zn-BTC metal organic framework assisted by a home microwave oven and their unusual morphologies," Materials Letters, vol. 182, pp. 231-234, 2016.

[22] H. Guo, T. Li, W. Chen et al., "General design of hollow porous $\mathrm{CoFe}_{2} \mathrm{O}_{4}$ nanocubes from metal-organic frameworks with extraordinary lithium storage," Nanoscale, vol. 6, pp. 1516815174, 2014

[23] S. Chen, M. Xue, Y. Li et al., "Porous $\mathrm{ZnCo}_{2} \mathrm{O}_{4}$ nanoparticles derived from a new mixed-metal organic framework for supercapacitors," Inorganic Chemistry Frontiers, vol. 2, pp. 177-183, 2015.
[24] H. D. Mai, K. Rafiq, and H. Yoo, "Nano metal-organic framework-derived inorganic hybrid nanomaterials: synthetic strategies and applications," Chemistry-A European Journal, vol. 23, pp. 5631-5651, 2017.

[25] X. Xu, K. Cao, Y. Wang, and L. Jiao, “3D hierarchical porous $\mathrm{ZnO} / \mathrm{ZnCo}_{2} \mathrm{O}_{4}$ nanosheets as high-rate anode material for lithium-ion batteries," Journal of Materials Chemistry A, vol. 4, pp. 6042-6047, 2016.

[26] G. Huang, F. Zhang, L. Zhang, X. Du, J. Wang, and L. Wang, "Hierarchical $\mathrm{NiFe}_{2} \mathrm{O}_{4} / \mathrm{Fe}_{2} \mathrm{O}_{3}$ nanotubes derived from metal organic frameworks for superior lithium ion battery anodes," Journal of Materials Chemistry A, vol. 2, pp. 8048-8053, 2014.

[27] R. Wu, X. Qian, K. Zhou, J. Wei, J. Lou, and P. M. Ajayan, "Porous spinel $\mathrm{Zn}_{x} \mathrm{Co}_{3-x} \mathrm{O}_{4}$ hollow polyhedra templated for high-rate lithium-ion batteries," ACS Nano, vol. 8, pp. 62976303, 2014.

[28] X. Lei, Y. Cao, Q. Chen, X. Ao, Y. Fang, and B. Liu, “ZIF-8 derived hollow $\mathrm{CuO} / \mathrm{ZnO}$ material for study of enhanced photocatalytic performance," Colloids and Surfaces A: Physicochemical and Engineering Aspects, vol. 568, pp. 1-10, 2019.

[29] T. T. Minh, N. H. Phong, H. Van Duc, and D. Q. Khieu, "Microwave synthesis and voltammetric simultaneous determination of paracetamol and caffeine using an MOF-199. based electrode," Journal of Materials Science, vol. 53, no. 4, pp. 2453-2471, 2018.

[30] H. Wang, X. Yuan, Y. Wu et al., "Synthesis and applications of novel graphitic carbon nitride/metal-organic frameworks mesoporous photocatalyst for dyes removal," Applied Catalysis B: Environmental, vol. 174-175, pp. 445-454, 2015.

[31] W.-T. Xu, L. Ma, F. Ke et al., "Metal-organic frameworks MIL-88A hexagonal microrods as a new photocatalyst for efficient decolorization of methylene blue dye," Dalton Transactions, vol. 43, pp. 3792-3798, 2014.

[32] V. Stavila, J. Volponi, A. M. Katzenmeyer, M. C. Dixon, and M. D. Allendorf, "Kinetics and mechanism of metal-organic framework thin film growth: systematic investigation of HKUST-1 deposition on QCM electrodes," Chemical Science, vol. 3, pp. 1531-1540, 2012.

[33] L. H. Wee, M. R. Lohe, N. Janssens, S. Kaskel, and J. A. Martens, "Fine tuning of the metal-organic framework $\mathrm{Cu}_{3}(\mathrm{BTC})_{2}$ HKUST-1 crystal size in the $100 \mathrm{~nm}$ to 5 micron range," Journal of Materials Chemistry, vol. 22, pp. 13742-13746, 2012.

[34] N. M. Mahmoodi and J. Abdi, "Nanoporous metal-organic framework (MOF-199): synthesis, characterization and photocatalytic degradation of basic blue 41," Microchemical Journal, vol. 144, pp. 436-442, 2019.

[35] T. V. N. Thi, C. L. Luu, T. C. Hoang et al., "Synthesis of MOF199 and application to $\mathrm{CO}_{2}$ adsorption," Advances in Natural Sciences: Nanoscience and Nanotechnology, vol. 4, no. 3, article 035016, 2013.

[36] X. Zhang, H. Li, X. Lv et al., "Facile synthesis of highly efficient amorphous Mn-MIL-100 catalysts: formation mechanism and structure changes during application in CO oxidation," Chemistry - A European Journal, vol. 24, no. 35, pp. 88228832, 2018.

[37] L. Cui, D. Zhao, Y. Yang, Y. Wang, and X. Zhang, "Synthesis of highly efficient $\alpha-\mathrm{Fe}_{2} \mathrm{O}_{3}$ catalysts for $\mathrm{CO}$ oxidation derived from MIL-100(Fe)," Journal of Solid State Chemistry, vol. 247, pp. 168-172, 2017.

[38] Y. Yang, H. Dong, Y. Wang, C. He, Y. Wang, and X. Zhang, "Synthesis of octahedral like Cu-BTC derivatives derived from 
MOF calcined under different atmosphere for application in CO oxidation," Journal of Solid State Chemistry, vol. 258, pp. 582-587, 2018.

[39] P. Sathishkumar, R. Sweena, J. J. Wu, and S. Anandan, "Synthesis of $\mathrm{CuO}-\mathrm{ZnO}$ nanophotocatalyst for visible light assisted degradation of a textile dye in aqueous solution," Chemical Engineering Journal, vol. 171, no. 1, pp. 136-140, 2011.

[40] S. Pal, S. Maiti, U. N. Maiti, and K. K. Chattopadhyay, "Low temperature solution processed $\mathrm{ZnO} / \mathrm{CuO}$ heterojunction photocatalyst for visible light induced photo-degradation of organic pollutants," CrystEngComm, vol. 17, no. 6, pp. 14641476, 2015.

[41] L. Xu, B. Wei, W. Liu, H. Zhang, C. Su, and J. Che, "Flower-like $\mathrm{ZnO}-\mathrm{Ag}_{2} \mathrm{O}$ composites: precipitation synthesis and photocatalytic activity," Nanoscale Research Letters, vol. 8, no. 1, p. 536, 2013.

[42] J. Tauc, "Optical properties and electronic structure of amorphous Ge and Si," Materials Research Bulletin, vol. 3, no. 1, pp. 37-46, 1968.

[43] K.-F. Lin, H.-M. Cheng, H.-C. Hsu, L.-J. Lin, and W.-F. Hsieh, "Band gap variation of size-controlled $\mathrm{ZnO}$ quantum dots synthesized by sol-gel method," Chemical Physics Letters, vol. 409, no. 4-6, pp. 208-211, 2005.

[44] Y. Xu and M. A. A. Schoonen, "The absolute energy positions of conduction and valence bands of selected semiconducting minerals," American Mineralogist, vol. 85, no. 3-4, pp. 543$556,2000$.

[45] Y. S. Chaudhary, A. Agrawal, R. Shrivastav, V. R. Satsangi, and S. Dass, "A study on the photoelectrochemical properties of copper oxide thin films," International Journal of Hydrogen Energy, vol. 29, no. 2, pp. 131-134, 2004.

[46] K. Santra, C. Sarkar, M. Mukherjee, and B. Ghosh, "Copper oxide thin films grown by plasma evaporation method," Thin Solid Films, vol. 213, no. 2, pp. 226-229, 1992.

[47] M. V. Lopez-Ramon, F. Stoeckli, C. Moreno-Castilla, and F. Carrasco-Marin, "On the characterization of acidic and basic surface sites on carbons by various techniques," Carbon, vol. 37, no. 8, pp. 1215-1221, 1999.

[48] B. Dhale, S. Mujawar, S. Bhattar, and P. Patil, "Chemical properties of $\mathrm{n}-\mathrm{ZnO} / \mathrm{p}-\mathrm{CuO}$ heterojunctions for photovoltaic applications," Der Chemica Sinica, vol. 5, pp. 59-64, 2014.

[49] H. Seema, K. C. Kemp, V. Chandra, and K. S. Kim, "Graphene- $\mathrm{SnO}_{2}$ composites for highly efficient photocatalytic degradation of methylene blue under sunlight," Nanotechnology, vol. 23, no. 35, article 355705, 2012.

[50] T. Shen, Z.-G. Zhao, Q. Yu, and H.-J. Xu, "Photosensitized reduction of benzil by heteroatom-containing anthracene dyes," Journal of Photochemistry and Photobiology A: Chemistry, vol. 47, no. 2, pp. 203-212, 1989.

[51] M. J. Islam, D. A. Reddy, J. Choi, and T. K. Kim, "Surface oxygen vacancy assisted electron transfer and shuttling for enhanced photocatalytic activity of a Z-scheme $\mathrm{CeO}_{2}$ - AgI nanocomposite," RSC Advances, vol. 6, no. 23, pp. 19341-19350, 2016.

[52] H. Fan, X. Zhao, J. Yang et al., "ZnO-graphene composite for photocatalytic degradation of methylene blue dye," Catalysis Communications, vol. 29, pp. 29-34, 2012.

[53] Y. Wang, R. Shi, J. Lin, and Y. Zhu, "Significant photocatalytic enhancement in methylene blue degradation of $\mathrm{TiO}_{2}$ photocatalysts via graphene-like carbon in situ hybridization," Applied Catalysis B: Environmental, vol. 100, no. 1-2, pp. 179-183, 2010.
[54] P. Du, A. Bueno-Lopez, M. Verbaas et al., "The effect of surface $\mathrm{OH}$-population on the photocatalytic activity of rare earthdoped $\mathrm{P} 25-\mathrm{TiO}_{2}$ in methylene blue degradation," Journal of Catalysis, vol. 260, no. 1, pp. 75-80, 2008.

[55] A. Houas, H. Lachheb, M. Ksibi, E. Elaloui, C. Guillard, and J.-M. Herrmann, "Photocatalytic degradation pathway of methylene blue in water," Applied Catalysis B: Environmental, vol. 31, no. 2, pp. 145-157, 2001.

[56] F. Jiang, T. Yan, H. Chen, A. Sun, C. Xu, and X. Wang, "Ag- $\mathrm{C}_{3} \mathrm{~N}_{4}-\mathrm{CdS}$ composite catalyst with high visible-lightdriven catalytic activity and photostability for methylene blue degradation," Applied Surface Science, vol. 295, pp. 164$172,2014$.

[57] T.-J. Whang, M.-T. Hsieh, and H.-H. Chen, "Visible-light photocatalytic degradation of methylene blue with laser-induced Ag/ZnO nanoparticles," Applied Surface Science, vol. 258, no. 7, pp. 2796-2801, 2012.

[58] J.-Z. Kong, A.-D. Li, X.-Y. Li et al., "Photo-degradation of methylene blue using Ta-doped $\mathrm{ZnO}$ nanoparticle," Journal of Solid State Chemistry, vol. 183, no. 6, pp. 1359-1364, 2010.

[59] D. A. Quang, T. T. T. Toan, T. Q. Tung, T. T. Hoa, T. X. Mau, and D. Q. Khieu, "Synthesis of $\mathrm{CeO}_{2} / \mathrm{TiO}_{2}$ nanotubes and heterogeneous photocatalytic degradation of methylene blue," Journal of Environmental Chemical Engineering, vol. 6, no. 5, pp. 5999-6011, 2018. 


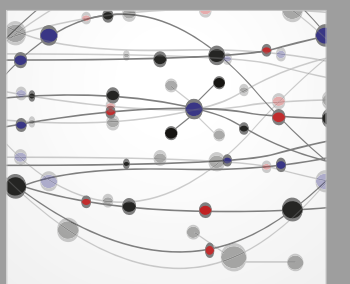

The Scientific World Journal
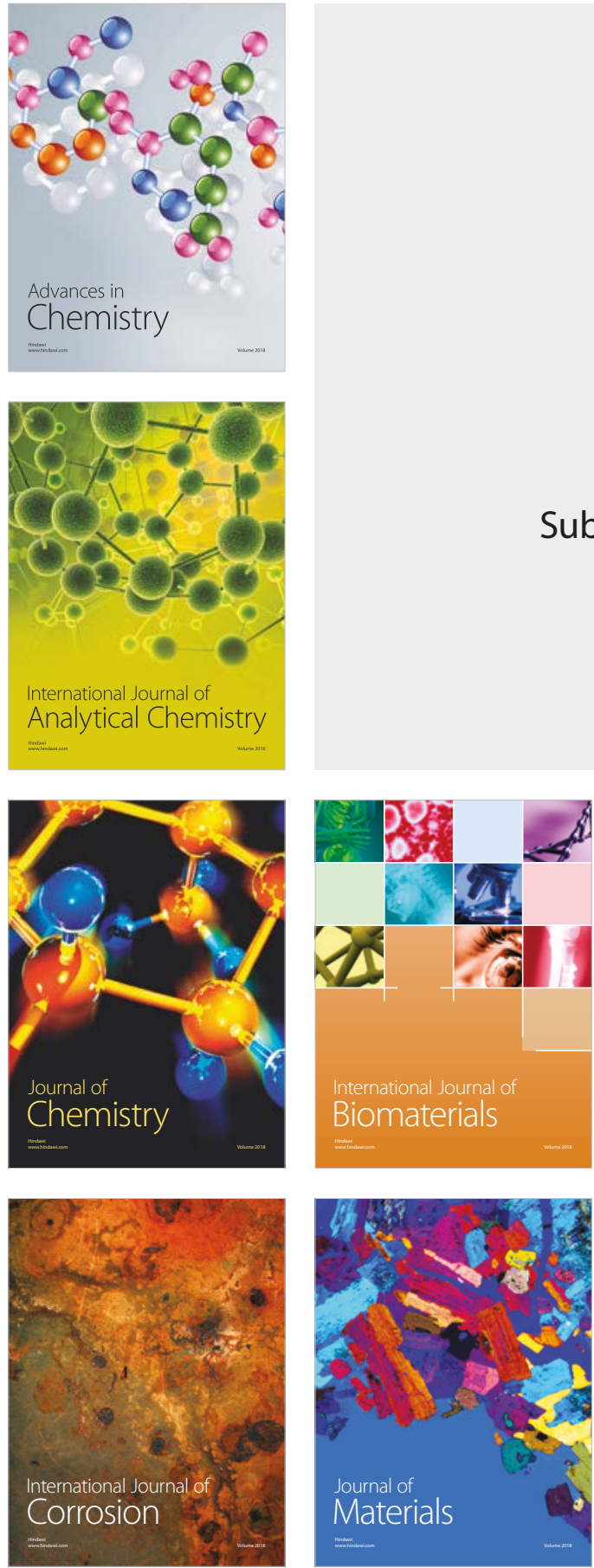



Journal of

Applied Chemistry
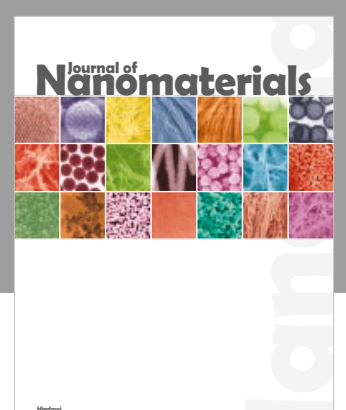

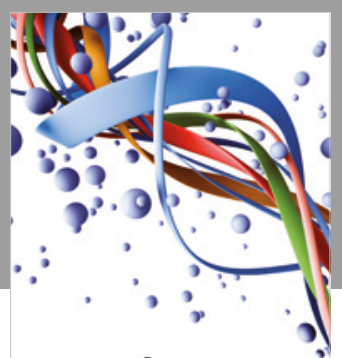

Scientifica



Polymer Science

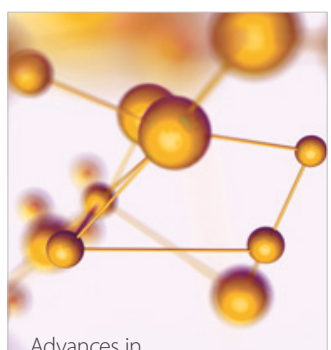

Physical Chemistry
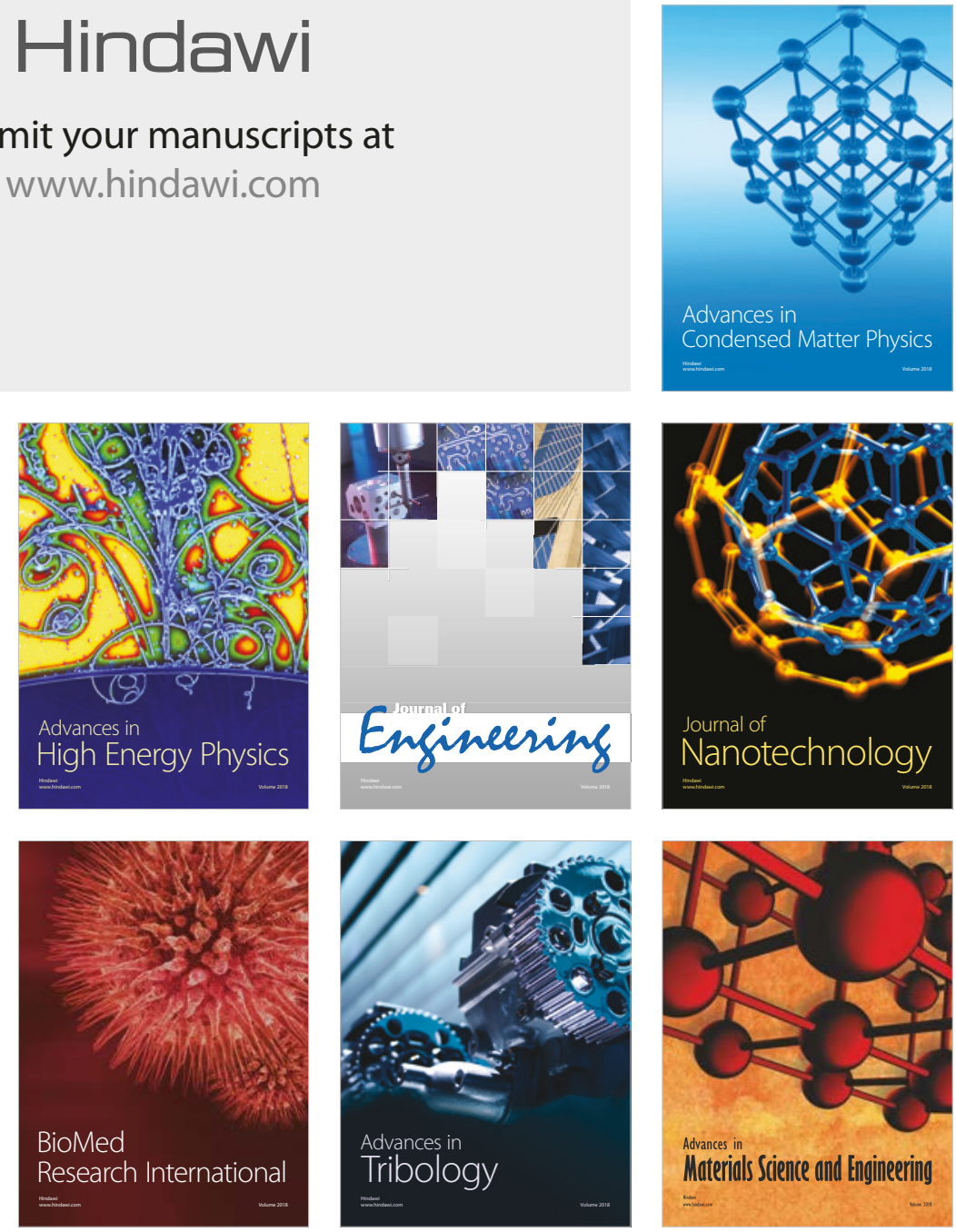